\title{
Entrepreneurial Networks and Open Innovation: The Role of Strategic and Embedded
}

Ties

\author{
Robert Huggins \\ School of Planning and Geography, \\ Cardiff University, \\ Glamorgan Building, \\ King Edward VII Avenue, \\ Cardiff, \\ CF10 3WA. \\ Email: hugginsr@cardiff.ac.uk \\ Phone: +44 (0) 2920876006 \\ Piers Thompson \\ Nottingham Business School, \\ Nottingham Trent University, \\ Burton Street, \\ Nottingham, \\ NG1 4BU. \\ Email: piers.thompson@ntu.ac.uk \\ Phone: +44 (0) 1158482143
}

\begin{abstract}
This paper considers the open innovation paradigm in the context of entrepreneurial firms. Based on an analysis of survey data, it examines the relationship between network ties and innovation. These are considered as the strategic network ties associated with open innovation and the embedded ties associated with entrepreneurial networks. It is found that both strategic and embedded ties are significantly associated with rates of innovation for entrepreneurial firms, although for the former this relationship is driven by a minority of larger or highly innovative firms. Strategic ties are most strongly linked to product and organisational innovations, whilst process innovations are more related to embedded network ties. There is some evidence of complementarity between the two forms of network tie. It is concluded that in the entrepreneurial context, the open innovation concept should be broadened to encompass the role performed by embedded network ties.
\end{abstract}

This is an Accepted Manuscript of an article published by Taylor \& Francis in Industry and

Innovation on $16^{\text {th }}$ November 2016, available online:

http://www.tandfonline.com/10.1080/13662716.2016.1255598. 


\title{
Entrepreneurial Networks and Open Innovation: The Role of Strategic and Embedded
}

Ties

\begin{abstract}
This paper considers the open innovation paradigm in the context of entrepreneurial firms. Based on an analysis of survey data, it examines the relationship between network ties and innovation. These are considered as the strategic network ties associated with open innovation and the embedded ties associated with entrepreneurial networks. It is found that both strategic and embedded ties are significantly associated with rates of innovation for entrepreneurial firms, although for the former this relationship is driven by a minority of larger or highly innovative firms. Strategic ties are most strongly linked to product and organisational innovations, whilst process innovations are more related to embedded network ties. There is some evidence of complementarity between the two forms of network tie. It is concluded that in the entrepreneurial context, the open innovation concept should be broadened to encompass the role performed by embedded network ties.
\end{abstract}

\section{Introduction}

With its emphasis on 'connect and develop', the emerging paradigm of 'open innovation' has provided important insights into the heightened role of knowledge accessing and networks in facilitating innovation and spurring the openness of innovation processes (Chesbrough, 2003, 2011; Chesbrough et al., 2006; Laursen and Salter 2006; Gassmann, 2006; Dahlander and Gann, 2010). A parallel and related stream of scholarly research has found interorganisational networks to be an important aspect of the innovation process, with network scholars stressing that innovation is a complex process often requiring knowledge flow between organisations (Ahuja, 2000; Lechner and Dowling, 2003; Owen-Smith and Powell, 2004; Vanhaverbeke, 2006; Roper et al., 2008; Tomlinson, 2010; Bergenholtz and 
Waldstrøm, 2011). Increasingly, this process is viewed as a systemic undertaking, i.e. organisations no longer innovate in isolation but through a complex set of interactions with other organisations (Huggins and Thompson, 2015). It is generally accepted that the networks underpinning innovation processes allow firms to access knowledge that they do not, or cannot, generate internally based on their own capabilities (Meagher and Rogers, 2004; Sammarra and Biggiero, 2008; Tomlinson, 2010).

In recent years, the term ‘open innovation’ has been coined to define the networked nature of innovation mechanisms. According to Chesbrough (2003, p. xxiv), open innovation is 'a paradigm that assumes that firms can and should use external ideas as well as internal ideas ... as the firms look to advance their technology’. Although existing evidence has mainly focused on open innovation in the context of large corporations, it may be a phenomenon equally applicable to a strata of more entrepreneurial firms (Laursen and Salter, 2006; Perkmann and Walsh, 2007; Lee et al., 2010). However, rather than the strategic and calculative tie formation largely associated with the notion of open innovation, much of the scholarly research on network tie formation in the context of entrepreneurship and entrepreneurial firms has focused on embedded ties, i.e. those rooted in social and interpersonal relationships that do not necessarily form part of the formal network strategies adopted by firms (Uzzi, 1996, 1997; Hite and Hesterly, 2001; Hayter, 2013; Huggins and Thompson, 2015). As a result, there is relatively little research concerning the extent to which these differing forms of networks ties are associated with innovation in the entrepreneurial context (Cetindamar and Ulusoy, 2008; Lhuillery and Pfister, 2009; Su et al., 2009; Hayter, 2013). Given the limited internal resources available to entrepreneurial firms, it may be a case of them not only having the capacity to access knowledge, but also the capability to absorb and combine this with existing knowledge that is crucial to fostering innovation (Huggins et al., 2012; Maurer and Ebers, 2006; Pickernell et al., 2011). It is possible that the value of 
network ties for innovation will differ by the type of network tie formed (Su et al., 2009), but also in terms of the type of innovation outcome (Fritsch and Schwirten, 1999; Pirolo and Presutti, 2010).

In essence, the aim of this paper is to empirically assess two theoretical strands of the entrepreneurial network literature - namely, the strategic tie discourse and second, the embedded tie discourse - to better understand how they may explain differences in innovation performance within the entrepreneurial context. The study seeks to bring these two strands of literature together to provide a more nuanced and holistic understanding of how different types of network tie may influence the innovative activity of enterprises. Furthermore, the study empirically examines the relationships present between different types of network tie and innovative activity and whether these are consistent with the existing theoretical literature. Therefore, the objective is to begin to unpack the blackbox of entrepreneurial networks from two perspectives: first, to provide a granular assessment of the differing ties entrepreneurial firms employ when engaged in sourcing knowledge for innovation; second, to provide an understanding of how differing ties relate to differing innovations. Such an approach would appear to be of value in terms of adding new theoretical insights to network theories of innovation-driven entrepreneurship. In particular, it seeks to address the following questions: (1) do strategic network ties have a positive relationship with the innovation performance of entrepreneurial firms? (2) do embedded network ties have a positive relationship with the innovation performance of entrepreneurial firms? (3) how do strategic and embedded networks relate to the forms of innovation undertaken in entrepreneurial firms? (4) to what extent are the roles played by strategic and embedded network ties complementary? and (5) in entrepreneurial firms with less resources, does absorptive capacity moderate the relationship between network ties and innovation? In order to examine these research questions the study utilises data from a unique study of 
entrepreneurial firms in the UK. In this case entrepreneurial firms are defined as those firms with significant entrepreneurial traits such as being opportunity seeking, and being growthoriented through an innovation-driven approach (Eisenhardt and Schoonhoven, 1996; Lechner and Dowling, 2003; Siegel et al., 2003; Huggins and Johnston, 2010). Controlling for other firm characteristics, negative binominal and zero-inflated Poisson regression analysis is used to explore the role of the two forms of network ties in aiding three types of innovation: product, process and organisational.

The remainder of the paper is structured as follows. The next section outlines the main literature on open innovation and the relationship between network ties and networks with innovation. The third section introduces the data utilised to test the relationships suggested by the literature and the analysis approaches to be utilised. The results are presented in the fourth section, with discussion and conclusions provided in the final section.

\section{Entrepreneurship, Networks and Innovation}

This section of the paper presents the conceptual framework guiding the empirical analysis, first introducing the objects of analysis in the form of entrepreneurial firms and the nature of their network ties, as well as the role of knowledge in the firm-network relationship. It then outlines how such network ties may influence the innovation performance of entrepreneurial firms, before discussing the potential role of internal absorptive capacity in moderating these outcomes.

\section{Entrepreneurial Firms, Networks and Knowledge}

As there is no accepted definition of an 'entrepreneurial firm' (Shane, 2012), the term has been employed in a number of different ways. For example, some studies have linked the concept to newly formed firms (Sharma and Chrisman, 1999), whilst others stress high growth potential (Carland et al., 2007), or independence (Daily et al., 2002). However, Shane 
(2012) suggests that rather than new firm formation that is key to the concept, it is the focus on identification, evaluation and exploitation of opportunities which distils the nature of the concept. As Alvarez and Barney (2004, page 631) argue, entrepreneurial firms “...exist in order to generate and appropriate the economic rents associated with market opportunities”. In this study, we recognise this by concentrating on those firms that are focused on such activities. Bhilde (2000) defines entrepreneurial firms as relatively young firms that have the potential of attaining significant size and profitability, so the focus again is on firms that may seek and exploit opportunities. Therefore, in many cases, these firms may be new, classed as small and medium sized enterprises (SMEs), or residing in knowledge intensive and hightechnology sectors, but this need not be the case. It is the 'opportunity' process and recognition that defines them, which in many ways can be considered congruent with the notion of 'innovation-driven' firms, and it is this nexus of heightened (significantly above average) opportunity-innovation practices that can be best considered to define entrepreneurial firms.

Although entrepreneurial firms are defined by their orientation towards opportunity identification and exploitation, they often face considerable constraints on the resources available to achieve this. These constraints may take the form of physical or financial capital, but can often reflect human capital limitations (Ortega-Argilés et al., 2009; Freel, 1999). Although they may be more productive in terms of creating research outputs (innovations) per unit of research input (R\&D expenditure) (van Dijk et al., 1997), due to a lack of internal resources, entrepreneurial firms are often reliant on external sources of knowledge as a means of innovating (Almeida et al., 2003; Anderson et al., 2010; Huggins et al., 2012). Even for larger firms this is becoming more important as innovation moves towards entire systems rather than individual products (Teece, 1998). Emerging theories of the firm such as the knowledge-based view (Grant, 1996) and extensions of the resource-based view (Eisenhardt 
and Schoonhoven, 1996; Lavie, 2006) recognise that the need to access knowledge is a key reason why firms build or enter networks with other organisations. These inter-organisational networks concern the interactions, relationships and ties existing between firms, and may arise through the need to access new technology, skills or expertise in order to keep pace with competitors (Ahuja, 2000). Inter-organisational networks in this context consist of the means by which knowledge flows across organisations beyond the direct purchasing of it.

In general, knowledge accessing from external organisations is considered to have become increasingly important to entrepreneurial firms (Freel, 2000, 2003; Hite and Hesterly, 2001; Yli-Renko et al., 2001; Almeida et al., 2003; Huggins and Johnston, 2009; Doran et al., 2012; Huggins and Thompson, 2015). In particular, within an entrepreneurial firm environment, the role of inter-organisational networks and knowledge sources are increasingly recognised as potentially important assets for creating and sustaining innovation and competitiveness (Lechner and Dowling, 2003). There is growing evidence that network development is related to the growth of firms, particularly networks involving the flow of knowledge (Knoben and Oerlemans, 2006). However, some studies have suggested that entrepreneurial firms may form network ties with the wrong actors for various reasons (Lechner and Dowling, 2003; Huggins and Thompson, 2015). For example, choosing to form ties to those in close cognitive proximity may allow easier understanding and access to knowledge, but much of this knowledge may be redundant and not new to the firm or the firm's existing network partners. Alternatively it may be a case of forming the right network ties at the right time initially, but then not adding to or even replacing ties when they lose their value and start to become redundant (Huggins and Johnston, 2010; Huggins et al., 2012).

Although scholarly work such as that outlined above has recognised the importance of networks for the success of entrepreneurial firms, a number of questions remain concerning 
the nature and form that these networks take to achieve the best outcomes (Uzzi, 1996, 1997; Hite and Hesterly, 2001; Hayter, 2013; Huggins and Thompson, 2015). Similarly, while the importance of open innovation and the associated network ties are increasingly recognised (Ter Wal and Boschma, 2011; Boschma et al., 2014), there is less agreement about the extent that differing network ties are equally effective for all types of innovation (Su et al., 2009). Equally, although networks may be formed with relevant actors, the internal resources of the entrepreneurial firm may remain key for utilising accessed knowledge (Huggins et al., 2012; Maurer and Ebers, 2006; Pickernell et al., 2011). These issues are outlined in more depth below.

\section{The Nature of Network Ties}

Entrepreneurial firms are often more likely to be dependent on embedded interpersonal social ties (Thorpe et al., 2005; Anderson et al., 2010). The different functions and objectives of a network can be defined as its 'compositional quality', which reflects the ability of differing network ties to provide needed resources (Hite and Hesterly, 2001). This compositional quality changes in much the same way that the resources required by a firm change as it evolves. The need to access resources and share risk is found to be particularly acute when firms are in vulnerable situations, such as those faced in emerging markets where the dominant technology and strategy is yet to materialise, and where competition is particularly high (Eisenhardt and Schoonhoven, 1996).

Existing evidence suggests that entrepreneurs build networks through a combination of calculative and social aspects (Johannisson et al., 2002; Schutjens and Stam, 2003; Anderson et al., 2007; Anderson et al., 2010). Initially, embedded social ties to geographically proximate actors may provide the key support to get ventures 'off-the-ground' (Uzzi, 1996, 1997; Stuart and Sorenson, 2003; Davidsson and Honig, 2003). Such ties may 
be formed with the entrepreneurs' friends, family, ex-colleagues or through membership of local business associations etc. (Hite, 2005; Klyver, 2007; Jack et al., 2010; Arregle et al., 2015). This is to be expected, since for new and growing firms the network requirements of both the firm and the firm’s operator (i.e. the entrepreneur) are likely to coincide, encompassing both his/her social and economic needs and objectives (Jack, 2005; Macpherson and Holt, 2007; Jack et al., 2008, 2010).

Interestingly, Westlund and Bolton (2003) present a persuasive case concerning some of the negative aspects of social networks among entrepreneurial firms, arguing that the strong trust embedded in interpersonal relations can inhibit firm-level development. This means that sourcing knowledge beyond a firm’s own capacity for knowledge creation, particularly outside of its technological area, often requires calculative efforts to nurture a capacity for searching appropriate knowledge sources beyond its corporate boundaries and the management of ensuing network relationships (Kay, 1993; Hite and Hesterly, 2001; Almeida et al., 2003; Chesbrough, 2003; Laursen and Salter, 2006). A shift away from embedded social networks may become evident when firms engage more in the formation of strategic ties based on formalised collaboration and joint ventures, and other 'contracted' relationships involving equity and R\&D agreements (Goerzen, 2005; Goerzen and Beamish, 2005; Grant, 1996; Grant and Baden-Fuller, 2004; Ireland et al., 2002; Stuart, 2000). Such networks are a type of asset formed through conscious, strategic investments in interactions allowing firms access to the knowledge they require to innovate and enhance economic returns (Huggins, 2010; Kramer and Revilla Diez, 2012; Kramer et al., 2011; Lawton Smith et al., 2012).

Strategic investments in this capacity are made possible through a combination of factors including the external orientation of management and employees, acceptance of related risks, and medium to long-term commitment to the strategy (Elmquist et al., 2009; 
Almirall and Casadesus-Masanell, 2010; Chiaroni et al., 2010; Dahlander and Gann, 2010; Huizingh, 2011), as well as the need to access new technology, skills, or expertise in order to keep pace with competitors (Ahuja, 2000; Huggins and Johnston, 2010). Therefore, there are likely to be variations across firms in the extent to which they make these particular types of investments and engage in external knowledge sourcing activities. Whilst variation is often found with regard to firm size and sector (e.g., Arora and Gambardella, 1990; Chesbrough and Crowther, 2006; Lee et al., 2010), it may also exist across firms of the same size or within the same sector due to differing strategic decisions (e.g., Rothwell and Dodgson, 1991; Chesbrough and Appleyard, 2007; Nakagaki et al., 2012; Chesbrough and Brunswicker, 2013).

Innovation outcomes

The literature discussed above has outlined how the types of network tie formed may be influenced by the needs of the firm, with different sources of knowledge holding different value at different points in time. Concentrating on innovation, however, it is unclear which form of network tie will be the most valuable. A vast majority of the research examining the impact on innovation from network ties does not differentiate between different types of innovation (Huggins et al., 2012). This means that there remains uncertainty as to whether the type of innovation in question plays a role, and what if any relationship exists between more strategically formed or socially embedded network ties.

A further complexity when attempting to ascertain the importance of external network ties for innovation is how to measure it. Although studies of innovation in larger organisations have traditionally used measures such as patent counts, this is not necessarily appropriate for all entrepreneurial firms where innovations may not be patented or in the case of organisational innovations unpatentable (Kitching and Blackburn, 1998; Huggins and 
Thompson, 2015). This means that innovation must be captured by more subjective or selfreported measures, which depending on their data collection could imply differing outcomes in studies considering a variety of relationships with innovation (Rosenbusch et al., 2011).

Traditionally, it has been suggested that knowledge flows that lead to innovation require access to tacit knowledge that is harder to communicate over a longer distance (Nonaka, 1991; Nonaka and Takeuchi, 1995). This implies that network ties at close proximity will have the greatest value in terms of the open innovation process (Maskell and Lorenzen, 2004). However, there is a growing acknowledgement that tightly bonded networks without access to global pipelines of knowledge may become stale and even counterproductive where technologies and processes become locked-in to out-dated modes (Adler and Kwon, 2002; Labianca and Brass, 2006; Maurer and Ebers, 2006). It is no surprise that where studies have considered varying forms of innovation, there are differences in the extent to which open innovation practices appear to be effective (Fritsch and Schwirten, 1999). For example, in university-corporate interactions, where innovative outcomes are yielded, this tends take the form of product rather than process innovation (Fritsch and Schwirten, 1999).

When focusing specifically on product development, it is argued that such innovative activities are becoming more collaborative, i.e. networked (Büyüközkan and Arsenyan, 2012), requiring calculatively developed and strategically maintained relationships between firms (Noori and Lee, 2004). The nature of these innovations often may require formal contracts to be developed to allow the relationship to function without the fear that knowledge will be appropriated or exploited by partners to the detriment of entrepreneurial firm (Faems et al., 2008). Contracts and written agreements cannot cover all eventualities in such relationships, and therefore a high level of cooperation and trust is required to successfully achieve the objectives of such partnerships, which means considerable efforts 
must be made to establish good relational governance (Bstieler and Hemmert, 2015). This would imply that strategic network ties would be most closely associated with product innovation. Bearing this out, it has been found that knowledge associated with both actual product innovations and innovative capacity are most positively associated with ties to actors located further afield (McEvily and Zaheer, 1999; Dunning, 2000; Lissoni, 2001; Davenport, 2005; Palazzo, 2005; Zaheer and Bell, 2005; Teixeira et al., 2006; Torré, 2008; Clifton et al., 2010).

In order to collaborate to achieve product innovation, firms’ cultures, institutions and organisations must be relatively proximate, to the point where firms may at some point in the future combine through merger or acquisition (Balland et al., 2015). This may mean that organisational innovations may actually occur as a bi-product of forming the strategic network ties developed for the purpose of achieving product innovation. However, some studies suggest that network ties with geographically proximate firms, which may be more embedded, gain from the 'local buzz' (Bathelt et al., 2004), reducing firm heterogeneity through the articulation of shared norms, standards, and rules of conduct among firms (Oliver 1997; Monge and Contractor 2003). This means that organisational innovation may be related to both strategic and embedded network ties, although in the case of the latter this may be to the detriment of future innovative activity, especially if networks become less dynamic and more homogeneous (Huggins et al., 2012).

Unlike product innovation, Capello (1999) argues that process innovations are developed on the basis largely of internal learning and resources, but are guided by proximity to suppliers and customers. It can be argued that strategic network ties are less likely to yield the tacit knowledge required for process innovations (Gopalakrishnan et al., 1999). Instead, relationships of cooperation, trust and friendship, which are more closely associated with 
embedded network ties, could potentially yield more positive outcomes (Casanueva et al., 2013).

The literature above suggests that particular types of innovation may be more closely associated with knowledge sources associated with either strategic or embedded network ties. However, other studies recognise that in terms of knowledge creation and innovation, network ties of different types may be complementary (Bathelt et al., 2004). Equally, there are the potential dangers of too closely bonded social relationships associated with embedded ties where networks become locked-in to particular development paths (Adler and Kwon, 2002; Labianca and Brass, 2006; Maurer and Ebers, 2006). It therefore remains an open question as to whether or not strategic and embedded network ties will exhibit a relationship more consistent with being complements or substitutes in the knowledge and innovation production process.

\section{Networks and Internal Capabilities/Resources}

As discussed above, external knowledge is perceived to be of growing importance for undertaking innovation activities (Huggins and Johnston, 2009; Doran et al., 2012), but it is argued that internal resources still play a key role (Chesbrough, 2003). This is because accessing knowledge is likely to be only one part of the story, with employing it successfully in the firm and combining it with existing knowledge to achieve innovative outcomes being quite another. Studies such as Cohen and Levinthal (1990) and Muscio (2007) suggest that beyond the skills and experience of management, the absorptive capacity of the firm as a whole is important in not only aiding the formation of collaborative arrangements with external organisations, but also in utilising the knowledge from the ties formed. Those businesses with greater absorptive capacity may be able to access knowledge from a wider variety of actors and usefully combine it with their own resources to aid innovation (Yli 
Renko and Autio, 1998; Yli Renko et al., 2001; Cohen and Levinthal 1990; Van Geenhuizen 2008). In a similar vein, Su et al. (2009) find that network ties in isolation have little benefit for increasing innovativeness with the exception of those made with universities and research institutes rather than suppliers, customers, and competitors.

The literature examined above indicates that whilst open innovation and network tie formation may seem to be an attractive proposition for entrepreneurial firms there is no guarantee that the network ties being formed by entrepreneurial firms will yield innovative outputs. There seems to be potential for variation in their effectiveness based on the types of network ties formed and the types of innovation being considered. All relationships also have the potential to be moderated by absorptive capacity. This means that there is a need for further analysis to examine the extent that network ties are productive in this regard.

\section{Data and Methods}

The analysis in this study is designed to establish the relationship between network ties and the innovation outputs of entrepreneurial firms in the UK. Furthermore, the focus of this study is not just on the relationship between network ties and innovation, but rather the types of network ties which are most strongly associated with innovation, and whether this varies by type of innovation. In order to establish the nature of these relationships, it is necessary to collect data specifically relating to the firms of importance to this study. Although the emphasis of the study is a subset of firms in the UK considered to be entrepreneurial, there is considerable heterogeneity within this group. This means that an analysis needs to be adopted that not only establishes whether any relationship exists between network ties and innovation, but is also able to separate out whether this reflects other characteristics of the firms rather than networking activities. This, therefore, requires a multivariate regression approach to be adopted. The remainder of the section outlines the data collection procedure and instrument 
used to develop appropriate measures of network ties and innovation, before outlining the analysis procedure used.

\section{Data Collection}

The empirical part of this paper is based on data collected from a survey of 3,622 firms in the UK to explore firm knowledge sourcing practices. The sample of firms was constructed from multiple regional and local directories of firms. Overall, the survey sought to capture firms with a potential propensity towards innovation and growth. Minguillo et al. (2015) outline the considerable evidence for science parks being sources of research and collaboration, and science and technology parks, and business incubators being regional sources of firms that are more science, technology, and innovation orientated (Squicciarini, 2009; Mian et al., 2012). Given this propensity toward innovation and growth, these firms can be considered to be entrepreneurial in their orientation, and are therefore considered to represent a cohort of analysable entrepreneurial firms (Shane, 2012; Bhilde, 2000; Alvarez and Barney, 2004). Data for the sample was enriched with firm-specific data derived from the FAME (Financial Analysis Made Easy) business database, which provided registered office address (important in the regional context), detailed sector classification (in the coding of UK Standard Industry Classification 2007) and employment data, as well as the year of incorporation, for which it is regarded as a reliable and robust source of information (Ritchie and Evans, 2009). Not only ensuring the capability to define the structure of the sample, this also helped to triangulate reported data with secondary data.

The survey sample focused mainly on three broad sectors: manufacturing; information and communication; and professional, scientific, and technical activities. Accounting for $86.7 \%$ of the sample, they were expected to capture the majority of the firms involved in the knowledge-sourcing activities. The remainder of the sectors included agriculture; mining; 
construction; wholesale and retail trade, and repair of motor vehicles and motorcycles; financial, insurance and real estate activities; human health and social work activities; arts, entertainment and recreation; and other service activities. As for firm size, the sample was formulated around the traditional three categories: small, medium, and large, which refer to employment of: 0-49, 50-249, 250 and more, respectively. The composition of the sample in terms of size was dominated by small firms (73.8 percent), with the medium firms constituting 19.8 percent and large firms 6.4 percent. In terms of geographical distribution, 42.7 percent of our sample were located in the South East, East of England, and London regions of the UK. The lowest proportion of firms came from Northern Ireland, Wales and North East regions (2.0 percent, 3.1 percent, and 3.3 percent respectively), which is representative of the distribution of the population of all active firms (Office for National Statistics, 2010).

The questionnaire was administered by post and achieved a response rate of 10.9 percent, which constituted 393 responses. For our current analytical purposes, we then selected 298 firms that answered all questions relevant to this paper’s analysis. In comparison with the sampled firms, $\chi^{2}$-test found that the selection was similar in terms of firm sizes, and geographical location, as shown by Table 1 . With regard to sector, there is a bias towards manufacturers, in particular high-technology manufacturers, with knowledge intensive services under-represented. This is not ideal and should be borne in mind when considering the bivariate relationships between innovation and network ties. In order to reduce the impact of this, multivariate regressions are utilised as discussed below in order to control for both manufacturing and degree of knowledge intensity.

\section{PLEASE INSERT TABLE 1 ABOUT HERE}


The survey collected information on knowledge sourcing activities by type and location of knowledge sources as well as firm profiles, with a mix of ordinal and scale data through the use of Likert scales and open numerical questions. The two main variables of interest within this study are those relating to innovation and network ties. In both cases the survey captured data reflecting overall measures as well as more disaggregated measures. In the case of innovation the focus was on those innovations introduced in the last three years. Respondents were asked to indicate the approximate number of product, process and organisational innovations introduced in this time period in response to the following survey items: how many new or significantly improved goods or services (e.g. in quality, user friendliness, timeliness) has your company introduced?; how many new or significantly improved methods for the production or supply of goods and/or services has your company introduced?; and how many times has your company introduced new or significantly improved forms of organisation, business structures or practices aimed at improving competitiveness (examples might relate to Investors in People, Just in Time, 6 Sigma and other major changes to structure or strategy)? This allows the third of the research questions to be addressed by considering specific types of innovation.

As such, all forms of innovation may be incremental or radical. Studies have suggested that entrepreneurial organisations may produce many of the radical innovations compared to more established firms, with their sunk investments and concern in protecting vested interests in existing products and processes (Huergo and Jaumandreu, 2004). However, it might still be expected that a majority of innovations, even in this sample, will still be incremental in nature. Although there is a danger of inaccuracy with regard to these measures of innovation, they are still likely to be preferable to alternatives such as patent counts which frequently are found not to capture a majority of innovations in SMEs (Kitching and Blackburn, 1998). The nature of the survey items, therefore, focuses on innovation in the 
sense of where this is important for the firm, rather than where it has been formalised in the form of a patent. In order to understand overall innovative activity within a firm an overall measure of innovation is simply the sum of all three measures of innovation. This overall measure is used to provide an indication of how network ties of different types relate to the overall innovation performance of the firm. However, with the types of innovation outlined above likely to be quite different, it makes this aggregation useful only for an illustrative initial analysis. It is also the case that different types of innovation will be more prevalent within different types of firms, which as will be discussed in more detail below needs to be taken into account. The more insightful analysis, therefore, is that between network ties and individual types of innovation.

Network ties are captured by two items, one relating to strategic network ties and one to embedded network ties, defined as: strategic network ties - relationships with the company’s knowledge sources which the company strategically seeks to maintain and develop; and embedded network ties - relationships the owners, managers, and employees of the company have with knowledge sources which the company does not strategically seek to maintain or develop. Therefore, by categorising the networking links of the firms it is possible to separately address the first two research questions outlined in the introduction. In each case the respondents were asked to rate on a scale of 0 (never) to 10 (very often) the frequency to which the firm uses each to source knowledge. An overall measure of network tie usage is generated from the sum of the frequency rating of strategic and embedded network ties. As with the innovation measures, this is purely for the purposes of establishing whether there is an overall linkage between network ties of all types and innovation, but as strategic and embedded network ties could display either substitute or complementary natures it is better to consider the network ties separately. 
A majority of studies on external knowledge sourcing behavior, particularly those drawing on variants of the Community Innovation Survey (CIS), measure the use of knowledge sources by binary dummies (e.g., Du et al., 2007; Roper et al., 2008, 2010; Tsai and Wang, 2009; Love et al., 2010; Doran and O’Leary, 2011) or four or five-point scales (Reichstein and Salter, 2006; Doran et al., 2012) while a small minority employ a 10-point scale (Belussi et al., 2010; Huggins et al., 2012). The 11 point scales used here allows greater insight into the frequency of use and degree of reliance on these external sources of knowledge. These measures have the advantage of reflecting the actual knowledge sourcing activities of the respondents rather than the simple presence of such network ties regardless of their use (Huggins et al., 2012). A disadvantage is that it is not possible to separate the use of different partners. This could be important given the suggestions of other studies that the diversity and evolution of knowledge sources is also an important factor in the value they create for the business (Maurer and Ebers, 2006; Huggins et al., 2015).

As discussed in the literature section and referred to in the fifth research question, an important moderating influence potentially determining the value of network ties for innovation outcomes is the absorptive capacity of the firm. Given the difficulty in capturing this objectively, the study has to rely upon the self-assessment of respondents in terms of their ability to absorb new knowledge. This is achieved by the response to the following item: to what extent is the internal resource base (skills, R\&D/innovation, IT and physical infrastructure, etc.) of your company sufficient to effectively utilise and implement the knowledge it sources externally? Respondents are asked to rate this as: extremely sufficient, significantly sufficient, partially sufficient, or not sufficient. The subjective measures have similarities with a combined measure of the internal resources utilised by others (Su et al., 2009), but with a focus on whether the respondent considers these resources provide the absorptive capacity to use external knowledge. This simplified measure was used to ensure 
higher response rates and avoid errors in the completion of more complex multiple items covering different individual capabilities. As relatively few businesses report their absorptive capacity as being not sufficient or only partially sufficient, we combine these categories. Regressions are run with dummies representing significantly sufficient and extremely sufficient absorptive capacity.

\section{Empirical Analysis Approach}

The analysis considers the relationship between network ties and each of the measures of innovative activity. This is firstly examined through the use of descriptive statistics to analyse whether those firms that more frequently use each type of tie display higher levels of innovative activity. A simple division is made between those that rated their use of a knowledge source above the mid-point value on the scale or otherwise. In the case of strategic and embedded network ties, this means those perceived to utilise the sources heavily are those providing a rating of more than 5 out of 10 . For the combined measure of ties, those classed as more frequently using network knowledge sources in general are those with a combined score greater than 10 . As the sample size is relatively small, non-parametric MannWhitney U-tests are used to examine whether significant differences exist between more frequent and less frequent users of each knowledge source.

As noted above, the nature of knowledge required and type of innovation conducted is likely to vary depending on the type of firm under consideration. Therefore, any relationship between network ties and innovation measures could be capturing other firm differences rather than between network ties and innovation. To account for the influence of other firm characteristics, Poisson and negative binominal regression analysis is used to further investigate the relationship between innovation and network ties. 
As the measures of innovation reflect counts of the number of a particular innovation activity, the variables are left censored and unlikely to be normally distributed. This is confirmed by the descriptive statistics outlined for the innovation variables and other control variables included in the regressions in Table 2 . The innovation variables are all positively skewed, reflecting the fact that a majority of firms in the sample have relatively few innovations, less than 15 over three years when aggregating all three types, but some have as many as 250 innovations during this period.

\section{PLEASE INSERT TABLE 2 ABOUT HERE}

The nature of the dependent variable makes ordinary least squares regressions inappropriate and an approach that accounts for the count nature of the variable such as a Poisson regression (Coleman, 1964) or negative binominal regression more appropriate. The Poisson regression fits the data to a Poisson distribution where the probability of the number of innovations (Inv) being $k$ is given by:

$$
\operatorname{Pr}\left(\operatorname{In} v_{i}=k_{i} \mid \mathbf{x}_{\mathbf{i}}\right)=\frac{e^{-\lambda_{i}} \lambda_{i}^{k_{i}}}{k_{i} !}
$$

Where $\lambda$ is commonly assumed to take the form of a log-linear model:

$$
\ln \lambda_{i}=\mathbf{x}_{\mathbf{i}}{ }^{\prime} \boldsymbol{\beta}=\beta_{0}+\beta_{1} \text { StratNet }_{i}+\beta_{2} \text { EmbedNet }_{i}+\boldsymbol{\beta}_{3} \mathbf{X}_{3, \mathbf{i}}
$$

Based on the literature explored in the preceding section, the incidence rate of innovations occurring is assumed to be a function of strategic network ties (StratNet) and embedded network ties (EmbedNet), and other firm characteristics as captured by vector $\mathbf{X}_{3}$.

The negative binominal regression is also appropriate for count based data and assumes that the data is distributed in a similar manner to the Poisson distribution. Where the negative binominal regression and Poisson regression differ is that the former allows for the 
data to be more widely dispersed than a true Poisson distribution, described as overdispersion. In a Poisson distribution the expected number of events per period and variance are assumed to be given by:

$E\left[k_{i} \mid \mathbf{x}_{\mathbf{i}}\right]=\operatorname{Var}\left[k_{i} \mid \mathbf{x}_{\mathbf{i}}\right]=\lambda_{i}=e^{\mathbf{x}_{\mathbf{i}}{ }^{\prime} \boldsymbol{\beta}}=e^{\beta_{0}+\beta_{1} \text { StratNet }_{i}+\beta_{2} \text { Embed }_{i}+\boldsymbol{\beta}_{3}{ }^{\prime} \mathbf{x}_{3, \mathbf{i}}}$

However, as the descriptive statistics in Table 2 suggest, the innovation variables are likely to reflect over-dispersion. The negative binominal regression accommodates this by including an individual, unobserved effect $\left(\varepsilon_{i}\right)$ in the conditional mean term:

$\ln \mu_{i}=\ln \lambda_{i}+\ln u_{i}=\mathbf{x}_{\mathbf{i}}{ }^{\prime} \boldsymbol{\beta}+\varepsilon_{i}=\beta_{0}+\beta_{1}$ StratNet $_{i}+\beta_{2}$ EmbedNet $_{i}+\boldsymbol{\beta}_{3} \mathbf{X}_{3, \mathbf{i}}+\varepsilon_{i}$

It is usually assumed that $u_{i}=e^{\varepsilon i}$ follows a gamma distribution normalised with an expected value of 1:

$g\left(u_{i}\right)=\frac{\theta^{\theta}}{\Gamma(\theta)} e^{-\theta u_{i}} u_{i}^{\theta-1}$

This means that the number of innovations is assumed to be distributed with an expected value of $\lambda_{i}$ as before, but a variance of $\lambda_{i}\left(1+(1 / \theta) \lambda_{i}\right)$. Where $\theta=0$ the distribution becomes a Poisson distribution. Given the descriptive data, a negative binominal regression is adopted to estimate the relationship between the different types of network ties and innovation. Whether a simpler Poisson regression would have been appropriate can be established by using a likelihood ratio test to whether $\theta$ is significantly different from zero.

A final set of alternatives are zero-inflated Poisson or negative binominal regressions (Greene, 1994). This is appropriate for data where the dependent variable incorporates two different decisions, a decision to engage in the measured activity, and a decision (or outcome) concerning the extent to which the activity is undertaken/achieved. In the case of the analysis here the decisions are whether to innovate or not, and if a firm chooses to innovate to what 
extent innovative outcomes are produced. The model works by fitting a logit (or probit) to capture the decision to innovate. If the logit indicates that there is a decision not to innovate a value of zero is estimated. If there is a decision to engage in innovative activity the model fits the Poisson or negative binominal regression to these observations. A firm can still be attempting to innovate, but produce no innovations if unsuccessful, so zeros are still a mix of those firms choosing not to innovate and those which are unsuccessful, but the former has been taken into account when determining the success of other firms' innovative activities. Whether this is an appropriate model or not can be determined by the Vuong (1989) test. This compares the predicted probability of $Y$ equals $y_{i}$ when distributed $f_{j}\left(y_{i} \mid \boldsymbol{x}_{i}\right)$ for models $j=1$ and 2.

\section{Regression Specifications}

Initially regressions are run with both types of network ties (embedded and strategic) included as independent variables, which provides insight into the first two research questions. The total innovation measure is utilised and all three of the potential regression models discussed above are utilised. This allows the most appropriate model to be identified and the results compared between the different models. However, the data indicates that there may be some outlier observations reflecting some large and/or particularly innovative firms, as is discussed in more detail in the next section. These may over influence the results found for the whole sample, in order to account for this a set of estimations is produced using a restricted sample that excludes any firms classed as large (250 employees or more), or any firms generating 50 or more innovations in the last three years (approximately the top 5 percent of firms in the sample).

Based on these results the model most appropriate for estimating the innovative activities of the entrepreneurial firms in the sample is utilised to examine the individual types 
of innovative activity, product, process and organisational innovations. This allows anexamination of whether particular types of network tie are more strongly associated with different types of innovation when seeking to address the third research question.

Although the two types of network tie may operate completely independently it is possible that such knowledge sources would not operate in this manner and as considered by research question four would have a complementary relationship. It is conceivable that the two types of network tie could act as both substitutes or complements to one another. In order to test this, the second specification also includes an interaction term between the two network tie variables. Where a complementary effect is present a positive coefficient would be expected to be estimated. Where the two sources of knowledge act as substitutes for one another, an insignificant result would be expected, unless diminishing returns are present due to informational redundancy, and where potentially a negative relationship between innovation and the interaction term may be generated. This can be tested more formally using the concept of supermodularity or submodularity. Complements exist for two variables $x^{\prime}$ and $x$ ’’ if the following is true (Topkis, 1995; 1998; Milgrom and Roberts, 1990, 1995; Milgrom and Shannon, 1994):

$F\left(x^{\prime} \vee x^{\prime \prime}\right)+F\left(x^{\prime} \wedge x^{\prime \prime}\right) \geq F\left(x^{\prime}\right)+F\left(x^{\prime \prime}\right) \quad \forall x^{\prime}, x^{\prime \prime} \in X$

Or

$$
F\left(x^{\prime} \vee x^{\prime \prime}\right)-F\left(x^{\prime}\right) \geq F\left(x^{\prime \prime}\right)-F\left(x^{\prime} \wedge x^{\prime \prime}\right) \quad \forall x^{\prime}, x^{\prime \prime} \in X
$$

Where $\left(x^{\prime} \vee x^{\prime}\right)$ is the maximum of $x^{\prime}$ and $x^{\prime \prime}$ and $\left(x^{\prime} \wedge x^{\prime \prime}\right)$ is the minimum. Equation (7) indicates that if the goods are complements adding $x$ ' to an existing level of $x^{\prime}$ will increase the value of the function by more in reaching the maximum than adding $x$ ' to the minimum level. In other words the addition of $x$ "' has a much larger impact on the output value achieved if some $x$ ' is present. Antonioli et al. (2013) use this approach to examine the 
complementarity of high performance work practices and human resource management on environmental innovation outputs. They operationalise the above equations by creating dummies to reflect whether: both variables are below the median (or mean), $\mathrm{H}(0,0)$; one variable is above the median and one below the median, $H(1,0)$; the second variable is above the median and the first below the median, $\mathrm{H}(0,1)$; and both variables are above the median, $\mathrm{H}(1,1)$. They include these dummies in regressions with the constant term supressed.

$$
\mathrm{Inn}_{i}=\beta_{0}+\beta_{1} x_{1 i}+\beta_{2} H(0,0)_{i}+\beta_{3} H(1,0)_{i}+\beta_{4} H(0,1)_{i}+\beta_{5} H(1,1)_{i}+\varepsilon_{i}
$$

A Wald test is then conducted on the coefficients attached to these dummies with the null hypothesis:

$$
\beta_{2}+\beta_{5}-\beta_{3}-\beta_{4}=0
$$

The network tie variables will be complements if the null can be rejected and reflective of equation (8) $\beta_{2}+\beta_{5}-\beta_{3}-\beta_{4}>0$, whilst the network ties being substitutes would be the case if $\beta_{2}+\beta_{5}-\beta_{3}-\beta_{4}<0$.

The final specification considers the role played by the absorptive capacity of the firm in accessing and utilising knowledge through networks (Cohen and Levinthal, 1990; Zahra and George, 2002). This is captured by including interaction terms between the absorptive capacity dummies and the individual network variables. Interactions are included with the individual network tie variables in order to allow for differences in the absorptive capacity required for knowledge drawn from different sources. As with the interaction between types of network tie, the total innovation dependent variable and full sample are utilised.

\section{Other Control Variables}

Other variables included in the regressions are intended to reflect those firm characteristics associated with changing innovation patterns. These include: internal resources as captured 
by firm's employment, micro (less than 10 employees), small (10 to 49 employees), medium (50 to 249 employees), and large (250 or more employees); firm age in three categories (1 to 3 years, 4 to 9 years, 10 years or older); high growth (sales growing by more than 50 per cent over the past three years); high-technology manufacturing or knowledge intensive services (the industry groups captured reflect the European Union (Eurostat, 2014) definitions ${ }^{1}$ ); and a dummy to reflect a manufacturing firm, as it would be expected that there would be differences in product innovation rates between these firms and others (Laursen and Salter, 2006; Mina et al., 2014). Within the zero-inflated Poisson and negative binominal specifications the variables are split with firm age, manufacturing and knowledge intensity modelling the decision to innovate or not and the remaining variables capturing the intensity of these activities. The age of the firm is included as part of the decision to innovate as studies such as Huggins et al. (2015) suggest that firms go through differing stages of network development where objectives change. The manufacturing dummy reflects the discussion above that product innovations may be less likely for non-manufacturing firms. It is only included in the logits when considering product and overall innovation. Equally less knowledge intensive firms may choose not to innovate given their differing entrepreneurial orientation.

\section{Results}

As would be expected given the entrepreneurial nature of surveyed firms, the overall rate of innovation activity is relatively high, with on average 15 innovations being produced by each firm over the past three years (Table 3). However, it is clear that there is considerable variation in the level of activity from firm to firm with a standard deviation of 29.3.

\footnotetext{
${ }^{1}$ The industry groups are defined at the two digit NACE revision 2 industry level. High-technology manufacturing includes those firms with the following industries: 21 and 26. Knowledge intensive services include the following industries: $50,51,58,59,60,61,62,63,64,65,66,69,70,71,72,73,74,75,78,80,84$, $85,86,87,88,89,90,91,92$ and 93 . All other industries are defined as less knowledge intensive.
} 


\section{PLEASE INSERT TABLE 3 ABOUT HERE}

Those firms indicating a more frequent use of all ties produced on average 20.2 innovations, compared to only 9.3 innovations for those drawing less frequently on these knowledge sources. This difference is found to be significant by the Mann-Whitney tests. This is consistent with those studies indicating that drawing on knowledge beyond the firm to achieve innovation is likely to be of importance to entrepreneurial firms (Laursen and Salter, 2006; Perkmann and Walsh, 2007). In cases where strategic network ties are more frequently used, innovation is higher, with frequent users of strategic network ties producing 18.4 innovations, on average, compared to only 10.1 innovations for less frequent users. This difference is significant, but only at the 5 percent level according to the Mann-Whitney test results.

Firms that most frequently use embedded network ties produce, on average, 22.4 innovations, compared to 10.5 for less frequent users. This difference is significant at the 1 percent level according to the Mann-Whitney tests. This suggests that although strategic network ties may be increasingly used by more established businesses (Hite and Hesterly, 2001; Goerzen, 2005), when considering those firms considered to be entrepreneurial in nature, embedded network ties may be more important and valued (Thorpe et al., 2005; Anderson et al., 2010).

The Pearson correlation coefficients for the dependent and independent variables are presented in Table 4. The correlation coefficients indicate that there is little problem with collinearity with perhaps the exception of the dummy representing manufacturing firms and the dummy denoting a knowledge intensive service or high-tech manufacturing firm. However, the variance inflation factors (VIF) from the regressions suggest no evidence of a 
problem with 3.4 the highest VIF found, well below the conventional cut-off level of 5. This was found on the dummy reflecting the oldest firms in the sample (10 years or more).

\section{PLEASE INSERT TABLE 4 ABOUT HERE}

In terms of the overall measure of innovation (Table 5), we report four different regression models, Poisson, negative binominal, zero-inflated Poisson and zero-inflated negative binominal, each run once with the full sample and once with a restricted sample as described in the previous section. The results for the four sets of regressions are very similar with regard to the focal network tie variables, although the different assumptions imposed do affect the number of significant terms generated. In general the Poisson regressions explain a larger proportion of the variance according to the Pseudo $R^{2}$ at 22.9 percent for the full sample, compared to only 4.1 percent for the negative binominal regressions. The chi-squared tests of collective significance are all significant suggesting that whilst a limited percentage of the variance is explained, the regressions outperform the null of a constant relationship. However, when choosing between the Poisson and negative binominal regressions, the likelihood ratio tests of $\theta$ indicate that it takes a value significantly different from zero. This indicates that over-dispersion is present as suspected from the descriptive values presented in Table 2, implying that a negative binominal regression is more appropriate than a Poisson regression. Comparing the zero-inflated Poisson and negative binomial regressions with the Poisson and negative-binominal regressions, there is no evidence from the Vuong test that such a regression is appropriate. Although the test statistic is positive it is not significant. For all innovations this comes as no surprise given the extremely small proportion of firms with zero innovations over the period (Greene, 2003).

\section{PLEASE INSERT TABLE 5 ABOUT HERE}


When using the full sample to consider the relationship between strategic and embedded network ties individually with innovation, both have a significant positive relationship with the count of all innovations. In the negative binominal regressions this relationship is strongest for more strategically developed and maintained network ties, as might be expected as firms overcome their early reliance on ties socially embedded in the entrepreneur's network, and more purposively seek sources of superior, miscible, and excludible knowledge (Hite and Hesterly, 2001; Antonelli, 2008; Quatraro 2010; Huggins and Thompson, 2014).

However, regardless of which regression model is applied the use of the restricted sample of less innovative and SMEs has a substantial effect on the regression results. Only the embedded network ties have a significant relationship with the number of innovations. It appears that the significant relationship between strategic ties and the number of innovations is driven by the outlier larger and extremely innovative organisations. In some regards it appears that strategic ties are potentially the most powerful network ties when seeking to innovate, but are not appropriate or cannot be maintained by a majority of the companies in the sample, even though these are more innovative organisations than the UK average (Lechner and Dowling, 2003). It appears, therefore, that the potential negative lock-in effects of embedded network ties that are likely to be bonding in nature are yet to manifest themselves in the sample of entrepreneurial firms examined here (Adler and Kwon, 2002; Westlund and Bolton, 2003; Maurer and Ebers, 2006). Overall the results indicate that for the first two research questions there is consistent evidence of a positive relationship between embedded network ties and innovation, but for strategic network ties the positive relationship found from the whole sample appears to be driven by a small number of outliers.

For the full sample there is a negative association between those with intermediate absorptive capacity (significant sufficient absorptive capacity), which could reflect over- 
confidence. It is only when using the restricted sample where the less innovative SMEs are considered that high levels of absorptive capacity play a role (extremely sufficient absorptive capacity). It could be the case that limited tangible internal resources are compensated for through these intangible resources (Cohen and Levinthal, 1990; Muscio, 2007). The results confirm the findings in Table 4 that larger firms on average have a higher number of innovations. Although some studies have recognised the flexibility and creativity of SMEs (Huergo and Jaumandreu, 2004), others have highlighted the limits on resources that the smallest firms face (micro firms in particular) (Baumann and Kritikos, 2016), and it appears that this latter consideration dominates.

Linked to the need to develop resources of all types the Poisson regressions provide evidence that older rather than new business starts produce significantly more innovations. As the older firms in the sample are not that old this may reflect a balance between the riskiness of innovative activities undertaken and the rewards earned. Whilst younger firms are likely to favour riskier innovative activities resulting in larger positive or negative payoffs older firms are more conservative (Coad, Segarra and Teruel, 2016), whilst such entrepreneurial firms in this sample may have found the correct balance. This is the opposite to those studies that find the flexibility of younger firms enables them to better take advantage of entrepreneurial-orientation in terms of growth (Anderson and Eshima, 2013). However, the results relating to firm age and size are consistent with those from other countries such as Finland (Heimonen, 2012). The Poisson regressions also indicate that manufacturing firms, because they are better placed to generate product innovations, are positively associated with greater innovations overall (Laursen and Salter, 2006; Mina et al., 2014). When the restricted sample is used the fast growing businesses are found to be more likely to innovate. Although this sample is a more innovative group of SMEs in general it is a 
result consistent with those studies that recognise that only a minority of SMEs are highly innovative (Cowling, 2016).

Moving on to the specific types of innovation Table 6 reports the regressions of the number of product, process and organisational innovations. Poisson regressions were run, but given the LR-tests for the dispersion variable, Vuong tests and the similarity of the results with those presented, for the preservation of space these are not reported.

\section{PLEASE INSERT TABLE 6 ABOUT HERE}

The results have a lot in common with those for all types of innovation; however, there are subtle differences in the significance of the network variables depending on the type of innovation being examined. When using the full sample according to the negative binominal regressions, the strategically formed network ties have a positive relationship with all three types of innovation. However, for process innovations such strategic network ties are only significant at the 10 percent level. Rather it is embedded network ties that display a significant relationship with process innovations. This may reflect the fact that process innovations are potentially developed largely on the basis of internal learning and resources, as well as being guided by proximity to suppliers and customers (Capello, 1999). Given that process innovations require more tacit knowledge (Gopalakrishnan et al., 1999), it is unlikely that strategic network ties can or would be developed to attempt to acquire such knowledge. This form of knowledge is more likely to be conveyed by relationships of cooperation, trust and friendship that are more closely associated with embedded network ties (Casanueva et al., 2013).

Embedded network ties are not as strongly related to product innovations as strategic network ties, but are significant at the 5 per cent level. This may reflect the role noted for trust and cooperation (Bstieler and Hemmert, 2015), but its lesser effect suggests that trustful 
commitment may suppresses opportunism - a key feature of an entrepreneurial firm (Yam and Chan, 2015). This is consistent with the literature that finds product development to be an increasingly collaborative process (Büyüközkan and Arsenyan, 2012), requiring calculatively developed and strategically maintained relationships between firms (Noori and Lee, 2004). Here, responsibilities and rewards are more likely to be formally established, allowing greater collaboration and openness of dealings without the fear of exploitation or misappropriation of knowledge (Faems et al., 2008). Relational governance also plays a role with past collaborations being important, suggesting a need for strategically maintained relationships to maximise the benefits for such innovative outputs (Bstieler and Hemmert, 2015).

Although embedded network ties are significantly related to product innovations for the full sample, embedded network ties are not significantly related to organisational innovations. Organisational innovations may be a bi-product of interactions associated with product innovation where firms’ cultures, institutions and organisations are relatively proximate, which allows the relationship to blossom (Balland et al., 2015).

Although not shown here, the zero-inflated Poisson regressions produce evidence of similar relationships (Table 6 Panel B), but generally with higher levels of significance. Overall both types of tie have a positive link with all types of innovation in the full sample. The Vuong tests indicate that the most appropriate times to consider these variables would be when considering process innovations, or organisational innovations with the restricted sample.

When concentrating on the restricted sample of smaller less innovative firms, the significant results from the negative binominal regressions relating to strategic network ties disappear for product and organisational innovations. This would be consistent with many 
smaller less innovative firms being unable to select and form successful ties with such partners (Lechner and Dowling, 2003). However, embedded network ties remain positively associated with product and organisational innovations. This appears to indicate that for a majority of the entrepreneurial firms examined here, whilst being less productive in terms of generating innovations, embedded network ties are more practical than strategic network ties, and do have a positive association with certain types of innovation. However, no such positive relationship remains between process innovations and embedded network ties, so for such innovation only the subsample of larger and more innovative enterprises are able to exploit knowledge sources of this type successfully (Kirkels and Duysters, 2010). Overall, with regard to the third research question it appears that the different types of innovation are related to the two types of network tie in a similar manner to total innovative activities.

Models were also run to include not only the two types of network tie, but to also allow interactions between the types of network tie and with absorptive capacity respectively (again, not shown here due to space restrictions). When an interaction term is added to capture any complementary effect of strategic and embedded network ties for innovative activities, the network variables lose their individual significance, suggesting that internal resources and external networks ties are not necessarily complementary.

Finally, to test further for the presence of complementarity in the relationships between innovation and the two types of network ties negative binominal regressions and zero-inflated Poisson regressions were run using the four dummies of above average network ties. When using the full sample, the negative binominal regressions for process and organisational innovation indicate relationships consistent with either a complementary or substitute relationship. The zero-inflated Poisson relationships indicate more evidence of complementarity, but where strategic and embedded network ties are above the median this has a substituting effect on organisational innovation. 


\section{Discussion and Conclusion}

This study has examined the role of the network ties of entrepreneurial firms in facilitating innovation, focusing on the type of strategic and calculative ties networks associated with the open innovation paradigm, as well as the more embedded social ties usually associated with entrepreneurial networks. In general, the results indicate that for entrepreneurial firms network ties as a means of accessing the knowledge have a positive relationship with innovation (Baum et al., 2000; Athreye, 2004; Garnsey and Heffernan, 2005). The study, however, sought to determine the relationship between strategic and embedded ties with rates of innovation independently. The results indicated that for these first two research questions there was evidence for both types of network tie having a significant relationship with innovation. However, for strategic network ties the relationship appears to be driven by a group of outlier larger highly innovative firms. For the majority of firms, only embedded network ties had a significantly positive effect, so for a majority of entrepreneurial firms strategic network ties may be harder to establish and to successfully utilise (Kirkels and Duysters, 2010; Uzzi, 1997).

The third research question considered the relationships with specific types of innovation and found that strategic ties displayed the strongest relationship with product and organisational innovations, whilst process innovations are more related to embedded network ties. Again strategic ties were relatively less important when outlier firms were removed. Potentially linked to smaller less innovative firms displaying limited evidence of a positive relationship between strategic network ties and innovation, evidence for a complementary relationship between the two sources of network ties was mixed providing an unclear answer for the fourth research question. There was even some evidence that the two may be substitutes in the case of process innovation. This may not mean that the two types of network tie cannot be used in a complementary fashion, but that as with the high performance 
work practices and human resource management in Antonioli et al.'s (2013) study most firms may not possess the capacity to do this. With regard to the focus of the fifth research question, the suggested moderating influence of absorptive capacity, was not supported.

From a theoretical perspective, the results suggest a number of useful insights, in the particular the dual role of both open innovation-type strategic networks and entrepreneurialtype embedded networks in fostering innovation, at least in an entrepreneurial context. Given this, it can be proposed that, when considering innovation-driven entrepreneurship, the open innovation concept is broadened to encompass a wider range of network ties than the strategic alliances, joint ventures and other contracted cooperative agreements with which it is normally associated. This is particularly the case when examining broader definitions of innovation than those normally captured by measures such as patent counts. Indeed, it may well be that within more established firms, embedded ties are of equal importance, as suggested by some emerging evidence (Mina et al., 2014), although more research is required to substantiate this. Given that there is some evidence for the mutual complementary effect of strategic and embedded ties on some types of innovation, it would seem that entrepreneurs and firms need to consider the balance of their portfolio of network ties, ensuring that they are neither under or overly embedded (Uzzi, 1996, 1997; Hite and Hesterly, 2001; Hayter, 2013). However, the influence of larger more successful highly innovative firms in driving these relationships, means that a majority of firms are not benefitting in this manner and may need support in realising the potential gains that are available through training and advice in terms of forming the correct strategic network ties.

Of course, in reality these ties are likely to be evolutionary and dynamic in nature, with ties that initially emerge through embedded relations morphing into more contractual and strategic relationships between firms, as well as other organisations. Similarly, whilst a strategic tie may have a particular lifespan, it may well generate more embedded ties that 
endure well beyond the agreement period of a formalised alliance or agreement. However, entrepreneurial firms are potentially vulnerable to seeing depletions of embedded ties due to their mobilisation being dependent on individuals who can leave the firm at any time, whereas the sovereignty of strategic ties are more likely to lie with the firm. This is important given that existing evidence tends to suggests that entrepreneurial networks tend to evolve from the embedded to the strategic state, whereby informal network actors that may initially be important sources of knowledge become, over time, key members of future strategic alliances networks (Huggins, 2010). Intuitively, this makes sense, since it is through repeated interaction that the trust required to form alliances is generated (Grabher and Ibert, 2006; Johannisson et al., 2002), and tends to confirm much of the literature suggesting that some form of underlying interdependence (e.g. an existing customer or supplier from which knowledge is already sourced, or membership of a common business or professional network) increases the propensity for the formation of future alliances (Gulati, 1999, 2007; Gulati and Gargiulo, 1999; Stuart, 1998). Given the cross-sectional nature of the data analysed here, it is not possible to perform such an evolutionary analysis, but it represents a potentially fruitful avenue for future research.

In terms of specific implications for entrepreneurs and their firms, the results make clear that external ties are positively related to innovation. However, entrepreneurs should be aware of the trade-offs that may exist between accessing knowledge that is relatively easy to source and absorb, and knowledge which may be more difficult to identify and integrate, but potentially offers far greater innovation potential. Therefore, entrepreneurs should ensure that management systems are in place to effectively search, screen and select the most appropriate knowledge to flow in and out of their firms. It is likely that in order to access the highest quality knowledge, entrepreneurs should seek to invest in a balanced portfolio of networks not only in terms of the nature of the tie, but also the nature of sources. Although 
entrepreneurial firms are unlikely to be able to bear the cost of full-time knowledge gatekeepers (Tushman and Katz, 1980; Rychen and Zimmermann, 2008; Belussi et al., 2010), more can be done to educate firms in the key principles of network management, as a feature of more general knowledge management practices. There are growing applied and professional disciplines related to the management of networks and knowledge flows, which should be supported through public policy (Huggins and Thompson, 2015).

In terms of the types of actors and knowledge sources with which ties are formed, some evidence suggests that entrepreneurial firms are often fearful of engaging in knowledge exchange partnerships with larger firms, particularly multinationals, due to worries concerning the exploitation of their knowledge base without receiving appropriate levels of financial reward (Lechner and Dowling, 2003; Huggins and Johnston, 2010). In the past, the assertion of intellectual property has been seen as the key means by which entrepreneurial firms are able to protect their knowledge. However, due to increasing problems of asserting rights in many sectors (e.g. services) and the cost and time implications of patenting and licensing agreements (Hipp and Grupp, 2005), this is not an option for all entrepreneurial firms, especially as larger firms are adopting open innovation strategies (Henkel et al., 2014). To an extent, the traditional intellectual property support available to entrepreneurial firms is likely to become less relevant as open innovation and open sourcing become ever more prevalent business practices (Chesbrough, 2003; von Hippel, 2005), and new policy initiatives are required to support these firms in ensuring they are equitably treated when establishing joint knowledge-based ventures and strategic alliances with larger firms.

Finally, it should be noted that this paper is clearly not without its limitations. The analysis presented here is necessarily exploratory and the cross-sectional nature of analysis limits the extent to which causal relationships can be identified. It draws on a specific cohort of entrepreneurial firms, which means that the results may not be fully generalisable across 
firms in other context and locations. However, the results do point to a number of interesting findings that could form the basis for more longitudinal and qualitative analysis that further seeks to integrate the propositions emerging from the parallel theories of open innovation and entrepreneurial networks.

\section{References}

Adler PS, Kwon SW. 2002. Social capital: prospects for a new concept. Academy of Management Review 27(1): 17-40.

Ahuja G. 2000. The duality of collaboration: Inducements and opportunities in the formation of interfirm linkages. Strategic Management Journal 21(3): 317-343.

Almeida P, Dokko G, Rosenkopf L. 2003. Startup size and the mechanisms of external learning: increasing opportunity and decreasing ability?. Research Policy 32(2): 301-315.

Almirall E, Casadesus-Masanell R. 2010. Open versus closed innovation: a model of discovery and divergence. Academy of Management Review 35(1): 27-47.

Alvarez SA, Barney JB. 2004. Organizing rent generation and appropriation: toward a theory of the entrepreneurial firm. Journal of Business Venturing 19(5): 621-635.

Anderson A, Park J, Jack S. 2007. Entrepreneurial social capital: conceptualizing social capital in new high-tech firms. International Small Business Journal 25(3): 245-272.

Anderson A, Dodd SD, Jack S. 2010. Network practices and entrepreneurial growth. Scandinavian Journal of Management 26(2): 121-133.

Anderson BS, Eshima Y. 2013. The influence of firm age and intangible resources on the relationship between entrepreneurial orientation and firm growth among Japanese SMEs. Journal of Business Venturing 28(3): 413-429.

Antonelli, C. (2008). Localised Technological Change: Towards the Economics of Complexity. Routledge: London.

Antonioli D, Mancinelli S, Mazzanti M. 2013. Is environmental innovation embedded within high-performance organisational changes? The role of human resource management and complementarity in green business strategies. Research Policy 42(4): 975-988.

Arora A, Gambardella A. 1990. Complementarity and external linkages: the strategies of the large firms in biotechnology. Journal of Industrial Economics 38(4): 361-379.

Arregle J-L, Batjargal B, Hitt MA, Webb JW, Miller T, Tsui AS. 2015. Family ties in entrepreneurs' social networks and new venture growth. Entrepreneurship Theory and Practice 39(2): 313-344.

Athreye S. 2004. Agglomeration and growth: A study of the Cambridge hi-tech cluster. In Building high-tech clusters Silicon Valley and beyond, Bresnahan T, Gambardella A (eds). Cambridge University Press: Cambridge and New York; 121-159. 
Balland P-A, Boschma R, Frenken K. 2015. Proximity and innovation: from statics to dynamics. Regional Studies 49(6): 907-920.

Bathelt H, Malmberg A, Maskell P. 2004. Clusters and knowledge: Local buzz, global pipelines and the process of knowledge creation. Progress in Human Geography 28(1): 3156.

Baum J, Calabrese T, Silverman BS. 2000. Don't go it alone: alliance network composition and startups' performance in Canadian biotechnology. Strategic Management Journal 21(3): 267-294.

Baumann J, Kritikos AS. 2016. The link between R\&D, innovation and productivity: are micro firms different? Research Policy 45(6): 1263-1274.

Belussi F, Sammarra A, Sedita SR. 2010. Learning at the boundaries in an "Open Regional Innovation System": A focus on firms' innovation strategies in the Emilia Romagna life science industry. Research Policy 39(6): 710-721.

Bergenholtz C, Waldstrøm C. 2011. Inter-organizational network studies: A literature review. Industry and Innovation 18(6): 539-562.Borgatti SP, Foster PC. 2003. The network paradigm in organizational research: a review and typology. Journal of Management 29(6): 991-1013.

Bhilde A. 2000. The Origin and Evolution of New Businesses. Oxford University Press: New York, NY.

Boschma R, Balland PA, de Vaan M. 2014. The formation of economic networks: a proximity approach. In Regional Development and Proximity Relations, Torre A, Wallet F (eds). Edward Elgar: Cheltenham; 243-266.

Bstieler L, Hemmert M. 2015. The effectiveness of relational and contractual governance in new product development collaborations: evidence from Korea. Technovation 45-46: 29-39.

Büyüközkan G, Arsenyan J. 2012. Collaborative product development: a literature overview. Production Planning and Control 23(1): 47-66.

Capello R. 1999. Spatial transfer of knowledge in high technology Milieux: learning versus collective learning processes. Regional Studies 33(4): 353-365.

Carland JW, Hoy F, Boulton WR, Carland JC. 2007. Differentiating entrepreneurs from small business owners: a conceptualization. in Á Cuervo, D Ribeiro, S Roig (eds.), Entrepreneurship: Concepts, Theory and Perspective, Berlin: Springer, pp. 73-81.

Casanueva C, Castro I, Galán JL. 2013. Informational networks and innovation in mature industrial clusters. Journal of Business Research 66(5): 603-613.

Cetindamar D, Ulusoy G. 2008. Innovation performance and partnerships in manufacturing firms in Turkey. Journal of Manufacturing Technology Management 19(3): 332-345.

Chesbrough H. 2003. Open Innovation: The New Imperative for Creating and Profiting from Technology. Harvard Business School Press: Boston, MA.

Chesbrough H. 2011. Open Services Innovation: Business Rethinking Your Business to Grow and Compete in a New Era. Jossey Bass: San Francisco, CA. 
Chesbrough H, Appleyard MM. 2007. Open innovation and strategy. California Management Review 50(1): 57-76.

Chesbrough H, Brunswicker S. 2013. Managing Open Innovation in Large Firms: Survey Report - Executive Survey on Open Innovation. Fraunhofer IAO: Stuttgart.

Chesbrough H, Crowther AK. 2006. Beyond high tech: Early adopters of open innovation in other industries. R\&D Management 36(3): 229-236.

Chesbrough H, Vanhaverbeke W, West J. (eds.) 2006. Open Innovation: Researching a New Paradigm. Oxford University Press: Oxford.

Chiaroni D, Chiesa V, Frattini F. 2010. Unravelling the process from closed to open innovation: evidence from mature, asset-intensive industries. R\&D Management 40(3): 222245.

Clifton N, Keast R, Pickernell D, Senior M. 2010. Network structure, knowledge governance, and firm performance: evidence from innovation networks and SMEs in the UK. Growth and Change 41(3): 337-373.

Coad A, Segarra A, Teruel M. 2016. Innovation and firm growth: does firm age play a role? Research Policy 45(): 387-400.

Cohen WM, Levinthal DA. 1990. Absorptive capacity: a new perspective on learning and innovation. Administrative Science Quarterly 35(1): 128-152.

Coleman JS. 1964. Introduction to Mathematical Sociology. Free Press: New York.

Cowling M. 2016. You can lead a firm to R\&D but can you make it innovate? UK evidence from SMEs. Small Business Economics 46(4): 565-577.

Dahlander L, Gann DM. 2010. How open is innovation?. Research Policy 39(6): 699-709.

Daily CM, McDougall PP, Covin JG, Dalton DR. 2002. Governance and strategic leadership in entrepreneurial firms. Journal of Management 28(3): 387-412.

Davenport S. 2005. Exploring the role of proximity in SME knowledge-acquisition. Research Policy 34(5): 683-701.

Davidsson P, Honig B. 2003. The role of social and human capital among nascent entrepreneurs. Journal of Business Venturing 18(3): 301-331.

Doran J, O’Leary E. 2011. External interaction, innovation and productivity: an application of the innovation value chain to Ireland. Spatial Economic Analysis 6(2): 199-222.

Doran J, Jordan D, O’Leary E. 2012. The effects of the frequency of spatially proximate and distant interaction on innovation by Irish SMEs. Entrepreneurship and Regional Development 24(7-8): 705-727.

Du J, Love JH, Roper S. 2007. The innovation decision: an economic analysis. Technovation 27(12): 766-773. 
Dunning JH. 2000. Regions, globalization, and the knowledge economy: the issues stated. In Regions, globalization, and the knowledge-based economy, Dunning JH (ed). Oxford University Press: Oxford; 7-41.

Eisenhardt KM, Schoonhoven CB. 1996. Resource-based view of strategic alliance formation: strategic and social effects in entrepreneurial firms. Organization Science 7(2): 136-150.

Elmquist M, Fredberg T, Ollila S. 2009. Exploring the field of open innovation. European Journal of Innovation Management 12(3): 326-345.

Eurostat 2014. Eurostat indicators of High-tech industry and knowledge - intensive services. Eurostat: Luxembourg.

Faems D, Janssens M, Madhok A, van Looy B. 2008. Toward an integrative perspective on alliance governance: connecting contract design, trust dynamics, and contract application. 51(6): 1053-1078.

Freel MS. 1999. Where are the skills gaps in innovative small firms?. International Journal of Entrepreneurial Behavior and Research 5(3): 144-154.

Freel MS. 2000. External linkages and product innovation in small manufacturing firms. Entrepreneurship and Regional Development 12(3): 245-266.

Freel MS. 2003. Sectoral patterns of small firm innovation, networking and proximity. Research Policy 32(5): 751-770.

Fritsch M, Schwirten C. 1999. Enterprise-university cooperation and the role of public research institutions in regional innovation systems. Industry and Innovation 6(1): 69-83.

Garnsey E, Heffernan P. 2005. High-technology clustering through spin-out and attraction: the Cambridge case. Regional Studies 39(8): 1127-1144.

Gassmann O. 2006. Opening up the innovation process: towards an agenda. R\&D Management 36(3): 223-228.

Goerzen A. 2005. Managing alliance networks: Emerging practices of multinational corporations. Academy of Management Executive 19(2): 94-107.

Goerzen A, Beamish PW. 2005. The effect of alliance network diversity on multinational enterprise performance. Strategic Management Journal 26(4): 333-354.

Gopalakrishnan S, Bierly P, Kessler EH. 1999. A re-examination of product and process innovations using a knowledge-based view. Journal of High Technology Management Research 10(1): 147-166.

Grabher G, Ibert O. 2006. Bad company? The ambiguity of personal knowledge networks. Journal of Economic Geography 6(3): 251-271.

Grant R. 1996. Toward a knowledge-based theory of the firm. Strategic Management Journal 17(S2): 109-122.

Grant R, Baden-Fuller C. 2004. A knowledge accessing theory of strategic alliances. Journal of Management Studies 41(1): 61-84. 
Greene WH. 1994. Accounting for excess zeros and sample selection in Poisson and negative binominal regression models. Department of Economics, Stern School of Business, New York University, \#EC-94-10.

Greene WH. 2003. Econometric Analysis Fifth Edition. Prentice Hall: Upper Saddle River, NJ.

Gulati R. 1999. Network location and learning: the influence of network resources and firm capabilities on alliance formation. Strategic Management Journal 20(5): 397-420.

Gulati R. 2007. Managing Network Resources: Alliances, Affiliations, and Other Relational Assets. Oxford University Press: Oxford.

Gulati R, Gargiulo M. 1999. Where do interorganizational networks come from?. American Journal of Sociology 104(5): 1439-1493.

Hayter CS. 2013. Conceptualizing knowledge-based entrepreneurship networks: perspectives from the literature. Small Business Economics 41(4): 899-911.

Heimonen T. 2012. What are the factors that affect innovation in growing SMEs? European Journal of Innovation Management 15(1): 122-144.

Henkel J, Schöberl S, Alexy O. 2014. The emergence of openness: how and why firms adopt selective revealing in open innovation. Research Policy 43(5): 879-890.

Hipp C, Grupp H. 2005. Innovation in the service sector: the demand for service-specific innovation measurement concepts and typologies. Research Policy 34(4): 517-535.

Hite J. 2005. Evolutionary processes and paths of relationally embedded network ties in emerging entrepreneurial firms. Entrepreneurship Theory and Practice 29(1): 113-144.

Hite J, Hesterly WS. 2001. The evolution of firm networks: from emergence to early growth of the firm. Strategic Management Journal 22(3): 275-286.

Huergo E, Jaumandreu J. 2004. Firms' age process innovation and productivity growth. International Journal of Industrial Organization 22(4):.541-559.

Huggins R. 2010. Forms of network resource: Knowledge access and the role of inter-firm networks. International Journal of Management Reviews 12(3): 335-352

Huggins R, Johnston A. 2009. Knowledge networks in an uncompetitive region: SME innovation and growth. Growth and Change 40(2): 227-259.

Huggins R, Johnston A. 2010. Knowledge flow and inter-firm networks: The influence of network resources, spatial proximity, and firm size. Entrepreneurship and Regional Development 22(5): 457-484.

Huggins R, Thompson P. 2014. A network-based view of regional growth. Journal of Economic Geography 14(3): 511-545.

Huggins R, Thompson P. 2015. Entrepreneurship, innovation and regional growth: a network theory. Small Business Economics 41(5): 103-128. 
Huggins R, Johnston A, Thompson P. 2012. Network capital, social capital and knowledge flow: how the nature of inter-organizational networks impacts on innovation. Industry and Innovation 19(3): 203-232.

Huggins R, Izushi H, Prokop D, Thompson P. 2015. Network Evolution and the Spatiotemporal Dynamics of Knowledge Sourcing. Entrepreneurship and Regional Development, 27 (7-8): 474-499.

Huizingh EKRE. 2011. Open innovation: state of the art and future perspectives. Technovation 31(1): 2-9.

Ireland RD, Hitt MA, Vaidyanath D. 2002. Alliance management as a source of competitive advantage. Journal of Management 28(3): 413-446

Jack SL. 2005. The role, use and activation of strong and weak network ties: A qualitative analysis. Journal of Management Studies 42(6): 1233-1259.

Jack S, Dodd SD, Anderson A. 2008. Change and the development of entrepreneurial networks over time: A processual perspective. Entrepreneurship and Regional Development 20(2): 125-159.

Jack S, Moult S, Anderson AR, Dodd S. 2010. An entrepreneurial network evolving: patterns of change. International Small Business Journal 28(4): 315-337.

Johannisson B, Ramírez-Pasillas M, Karlsson G. 2002. The institutional embeddedness of local inter-firm networks: a leverage for business creation. Entrepreneurship and Regional Development 14(4): 297-315.

Kay J. 1993. Foundations of Corporate Success: How Strategies Add Value. Oxford University Press: Oxford.

Kirkels Y, Duysters G. 2010. Brokerage in SME networks. Research Policy 39(3), 375-385.

Kitching J, Blackburn R. 1998. Intellectual property management in the small and medium enterprise (SME). Journal of Small Business and Enterprise Development 5(4): 327-335.

Klyver K. 2007. Shifting family involvement during the entrepreneurial process. International Journal of Entrepreneurial Behaviour and Research 13(5): 258-277.

Knoben J, Oerlemans LAG. 2006. Proximity and inter-organizational collaboration: a literature review. International Journal of Management Reviews 8(2): 71-89.

Kramer J-P, Marinelli E, Iammarino S, Revilla Diez J. 2011. Intangible assets as drivers of innovation: Empirical evidence on multinational enterprises in German and UK regional systems of innovation. Technovation 31(9): 447-458.

Kramer J-P, Revilla Diez J. 2012. Catching the local buzz by embedding? Empirical insights on the regional embeddedness of multinational enterprises in Germany and the UK. Regional Studies 46(10): 1303-1317.

Labianca G, Brass DJ. 2006. Exploring the social ledger: negative relationships and negative asymmetry in social networks in organizations. Academy of Management Review 31(3): 596-614. 
Laursen K, Salter A. 2006. Open for innovation: the role of openness in explaining innovation performance among U.K. manufacturing firms. Strategic Management Journal 27(2), 131-150.

Lavie D. 2006. The competitive advantage of interconnected firms: an extension of the resource-based view. Academy of Management Review 31(3): 638-658.

Lawton Smith H, Romeo S, Virahsawmy M. 2012. Business and professional networks: scope and outcomes in Oxfordshire. Environment and Planning A 44(8): 1801-1818.

Lechner C, Dowling M. 2003. Firm networks: external relationships as sources for the growth and competitiveness of entrepreneurial firms. Entrepreneurship and Regional Development 15(1): 1-26.

Lee, S., Park, G., Yoon, B., Park, J., 2010. Open innovation in SMEs - An intermediated network model. Research Policy 39 (2): 290-300.

Lhuillery S, Pfister E. 2009. R\&D cooperation and failures in innovation projects: empirical evidence from French CIS data. Research Policy 38(1): 45-57.

Lissoni F. 2001. Knowledge codification and the geography of innovation: the case of Brescia mechanical cluster. Research Policy 30(9): 1479-1500.

Love JH, Roper S, Hewitt-Dundas N. 2010. Service innovation, embeddedness and business performance: evidence from Northern Ireland. Regional Studies 44(8): 983-1004.

Macpherson A, Holt R. 2007. Knowledge, learning and small firm growth: a systematic review of the evidence. Research Policy 36(2): 172-192.

Maskell P, Lorenzen M. 2004. The cluster as market organization. Urban Studies 41(5/6): 991-1009.

Maurer I, Ebers M. 2006. Dynamics of social capital and their performance implications: lessons from biotechnology start-ups. Administrative Science Quarterly 51(2): 262-292.

McEvily B, Zaheer A. 1999. Bridging ties: a source of firm heterogeneity in competitive capabilities. Strategic Management Journal 20(12): 1133-1156.

Meagher K, Rogers M. 2004. Network density and R\&D spillovers. Journal of Economic Behavior and Organization 53(2): 237-260.

Mian S, Fayolle A, Lamine W. 2012. Building sustainable regional platforms for incubating science and technology businesses: evidence from US and French science and technology parks. International Journal of Entrepreneurship and Innovation 13(4): 235-247.

Milgrom P, Roberts J. 1990. The economics of modern manufacturing: technology, strategy and organization. American Economic Review 80(3): 511-528.

Milgrom P, Roberts J. 1995. Complementarities and fit strategy, structure and organizational change in manufacturing. Journal of Accounting Economics 19(2/3): 179-208.

Milgrom P, Shannon C. 1994. Monotone comparative statics. Econometrica 62(1): 157-180. 
Mina A, Bascavusoglu-Moreau E, Hughes A. 2014. Open service innovation and the firm's search for external knowledge. Research Policy 43(5): 853-866.

Minguillo D, Tijssen R, Thelwall M. 2015. Do science parks promoted research and technology? A scientometric analysis of the UK. Scientometrics 102(1): 701-725.

Monge PM, Contractor NS. 2003. Theories of communication networks. Oxford University Press: New York.Muscio A. 2007. The impact of absorptive capacity on SMEs' collaboration. Economics of Innovation and New Technology 16(8): 653-668.

Muscio A. 2007. The impact of absorptive capacity on SMEs collaboration. Economics of Innovation and New Technology 16(8): 653-668.

Nakagaki P, Aber J, Fetterhoff T. 2012. The challenges in implementing open innovation in a global innovation-driven corporation. Research-Technology Management 55(4): 32-38.

Nonaka I. 1991. The knowledge-creating company. Harvard Business Review 69(6): 96-104.

Nonaka I, Takeuchi H. 1995. The Knowledge-creating Company: How Japanese Companies Create the Dynamics of Innovation. Oxford University Press: New York, NY.

Noori H, Lee WB. 2004. Collaborative design in a networked enterprise: the case of the telecommunications industry. International Journal of Production Research 42(15): 30413054.

Office for National Statistics. 2010. Business Demography 2010. http://www.ons.gov.uk/ons/rel/bus-register/business-demography/2010/stb_---businessdemography-2010.html [15 March 2012].

Oliver C. 1997. Sustainable competitive advantage: combining institutional and resource-based views. Strategic Management Journal, 18(9): 697-713.

Ortega-Argilés R, Vivarelli M, Voight P. 2009. R\&D in SMEs: a paradox?. Small Business Economics 33(1): 3-11.

Owen-Smith J, Powell WW. 2004. Knowledge networks as channels and conduits: the effects of spillovers in the Boston biotechnology community. Organizational Science 15(1): 5-21.

Palazzo G. 2005. Postnational constellations of innovativeness: a cosmopolitan approach. Technology Analysis and Strategic Management 17(1): 55-72.

Perkmann M, Walsh K. 2007. University-industry relationships and open innovation: towards a research agenda. International Journal of Management Reviews 9(4): 259-280.

Pickernell D, Packham G, Jones P, Miller C, Thomas B. 2011. Graduate entrepreneurs are different: the have more knowledge?. International Journal of Entrepreneurial Behaviour and Research 17(2): 183-202.

Pirolo L, Presutti M. 2010. The impact of social capital on the start-ups' performance growth. Journal of Small Business Management 48(2): 197-227.

Quatraro F. 2010. Knowledge coherence, variety and economic growth: manufacturing evidence from Italian regions. Research Policy 39(10): 1289-1302. 
Reichstein T, Salter A. 2006. Investigating the sources of process innovation among UK manufacturing firms. Industrial and Corporate Change 15(4): 653-682.

Ritchie F, Evans P. 2009. UK Company Statistics Reconciliation Project, Final Report. Department for Business, Enterprise and Regulatory Reform: London.

Roper S, Du J, Love JH. 2008. Modelling the innovation value chain. Research Policy 37(67): 961-977.

Roper S, Youtie J, Shapira P, Fernández-Ribas A. 2010. Knowledge, capabilities and manufacturing innovation: a USA-Europe comparison. Regional Studies 44(3): 253-279.

Rosenbusch N, Brinckman J, Bausch A. 2011. Is innovation always beneficial? A metaanalysis of the relationship between innovation and performance in SMEs. Journal of Business Venturing 26(4): 441-457.

Rothwell R, Dodgson M. 1991. External linkages and innovation in small and medium-sized enterprises. R\&D Management 21(2): 125-138.

Rychen F, Zimmermann J-B. 2008. Clusters in the global knowledge-based economy: knowledge gatekeepers and temporary proximity. Regional Studies 42(6): 767-776.

Sammarra A, Biggiero L. 2008. Heterogeneity and specificity of inter-firm knowledge flows in innovation networks. Journal of Management Studies 45(4): 800-829.

Schutjens V, Stam E. 2003. The evolution and nature of young firm networks: a longitudinal perspective. Small Business Economics 21(2): 115-134.

Shane S. 2012. Reflections on the 2010 AMR decade award: delivering on the promise of entrepreneurship as a field of research. Academy of Management Review 37(1): 10-20.

Sharma P, Chrisman JJ. 1999. Toward a reconciliation of the definitional issues in the field of corporate entrepreneurship. Entrepreneurship, Theory and Practice 23(3): 11-27.

Siegel DS, Wessner C, Binks M, Lockett A. 2003. Policies promoting innovation in small firms: evidence from the U.S. and U.K. Small Business Economics 20(2): 121-127.

Squicciarini M. 2009. Science parks: seedbeds of innovation? A duration analysis of firms' patenting activity. Small Business Economics 32(2): 169-190.

Stuart TE. 1998. Network positions and propensities to collaborate: an investigation of strategic alliance formation in a high-technology industry. Administrative Science Quarterly 43(3): 668-698.

Stuart TE. 2000. Interorganizational alliances and the performance of firms: a study of growth and innovation rates in a high-technology industry. Strategic Management Journal 21(8): 791-811.

Stuart T, Sorenson O. 2003. The geography of opportunity: spatial heterogeneity in founding rates and the performance of biotechnology firms. Research Policy 32(2): 229-253.

Su Y-S, Tsang EWK, Peng MW. 2009. How do internal capabilities and external partnerships affect innovativeness?. Asia Pacific Journal of Management 26(2): 309-331. 
Teece, D. J. 1998. Capturing value from knowledge assets: The new economy, markets for know-how, and intangible assets. California Management Review 40(3): 55-79.

Teixeira A, Santos P, Oliveira Brochado A. 2006. Does proximity really matter in international R\&D cooperative projects?. In European Network on Industrial Policy (EUNIP) 9th International Conference, Limerick, Ireland.

Ter Wal ALJ, Boschma R. 2011. Co-evolution of firms, industries and networks in space. Regional Studies 45(7): 919-933.

Thorpe R, Holt R, Macpherson A, Pittaway L. 2005. Using knowledge within small and medium-sized firms: a systematic review of the evidence. International Journal of Management Reviews 7(4): 257-281.

Tomlinson P. 2010. Co-operative ties and innovation: some new evidence for UK manufacturing. Research Policy 39(6): 762-775.

Topkis DM. 1995. Comparative statistics of the firm. Journal of Economic Theory 67(2): 370-401.

Topkis DM. 1998. Super Modularity and Complementarity. Princeton University Press: Princeton, NJ.

Torré A. 2008 On the role played by temporary geographical proximity in knowledge transmission. Regional Studies 42(6): 869-889.

Tsai K-H, Wang J-C. 2009. External technology sourcing and innovation performance in LMT sectors: an analysis based on the Taiwanese Technological Innovation Survey. Research Policy 38(3): 518-526.

Tushman M L, Katz R. 1980. External communication and project performance: an investigation into the role of gatekeepers. Management Science 26(11): 1071-1085.

Uzzi B. 1996. The sources and consequences of embeddedness for the economic performance of organizations: the network effect. American Sociological Review 61(4): 674-698.

Uzzi B. 1997. Social structures and competition in interfirm networks: the paradox of embeddedness. Administrative Science Quarterly 42(1): 35-67.

Van Dijk B, Hertog RD, Menkveld B Thurik R. 1997. Some new evidence on the determinants of large and small-firm innovation. Small Business Economics 9(4): 335-343.

van Geenhuizen M. 2008. Knowledge networks of young innovators in the urban economy: biotechnology as a case study. Entrepreneurship \& Regional Development 20(2): 161-183.

Vanhaverbeke W. 2006. The inter-organizational context of open innovation. In Open Innovation: Researching a New Paradigm, Chesbrough H, Vanhaverbeke W, West J (eds). Oxford University Press: Oxford; 205-219.

von Hippel E. 2005. Democratizing innovation. MIT Press: Cambridge, MA.

Vuong Q. 1989. Likelihood ratio tests for model selection and non-nested hypotheses. Econometrica 57(): 307-334. 
Westlund H, Bolton R. 2003. Local social capital and entrepreneurship. Small Business Economics 21(1): 77-113.

Yam RCM, Chan C. (2015) Knowledge sharing, commitment and opportunism in new product development. International Journal of Operations and Production Management 35(7): 1056-1074.

Yli-Renko H, Autio E. 1998. The network embeddedness of new technology-based firms: developing a systematic evolution model. Small Business Economics 11(6/7): 253-267.

Yli-Renko H, Autio E, Sapienza HJ. 2001. Social capital, knowledge acquisition, and knowledge exploitation in young technology-based firms. Strategic Management Journal 22(6/7): 587-613.

Zaheer A, Bell G. 2005. Benefiting from network position: firm capabilities, structural holes, and performance. Strategic Management Journal 26(9): 809-825.

Zahra SA, George G. 2002. Absorptive capacity: a review, reconceptualization, and extension. Academy of Management Review 27(2): 185-203. 
Table 1: Breakdown of the firm sample and responding firms by size, sector and region (percentage of total sample/responses)

\begin{tabular}{|c|c|c|c|c|c|c|c|c|}
\hline Size & Sample & Respondents & Sector & Sample & Respondents & Region & Sample & Respondents \\
\hline Small & $69.2 \%$ & $73.8 \%$ & $\begin{array}{l}\text { High technology } \\
\text { manufacturing } \\
\text { Medium-high }\end{array}$ & $2.1 \%$ & $14.1 \%$ & East Midlands & $5.4 \%$ & $5.0 \%$ \\
\hline Medium & $20.7 \%$ & $19.8 \%$ & $\begin{array}{l}\text { technology } \\
\text { manufacturing } \\
\text { Medium-low } \\
\text { technology }\end{array}$ & $8.4 \%$ & $8.7 \%$ & $\begin{array}{l}\text { East of } \\
\text { England }\end{array}$ & $13.0 \%$ & $13.8 \%$ \\
\hline \multirow[t]{10}{*}{ Large } & $10.1 \%$ & $6.3 \%$ & $\begin{array}{l}\text { manufacturing } \\
\text { Low technology }\end{array}$ & $10.7 \%$ & $8.1 \%$ & London & $12.7 \%$ & $10.4 \%$ \\
\hline & & & $\begin{array}{l}\text { manufacturing } \\
\text { Knowledge-intensive }\end{array}$ & $5.9 \%$ & $5.4 \%$ & $\begin{array}{l}\text { North East } \\
\text { Northern }\end{array}$ & $3.3 \%$ & $2.7 \%$ \\
\hline & & & $\begin{array}{l}\text { services } \\
\text { Low knowledge- }\end{array}$ & $67.1 \%$ & $55.4 \%$ & Ireland & $2.0 \%$ & $2.0 \%$ \\
\hline & & & $\begin{array}{l}\text { intensive services } \\
\text { Other non-technology }\end{array}$ & $1.7 \%$ & $5.4 \%$ & North West & $9.6 \%$ & $11.7 \%$ \\
\hline & & & services & $4.1 \%$ & $3.0 \%$ & Scotland & $8.2 \%$ & $5.4 \%$ \\
\hline & & & & & & South East & $17.1 \%$ & $15.4 \%$ \\
\hline & & & & & & South West & $6.7 \%$ & $8.4 \%$ \\
\hline & & & & & & $\begin{array}{l}\text { Wales } \\
\text { West }\end{array}$ & $3.1 \%$ & $4.4 \%$ \\
\hline & & & & & & Midlands & $11.8 \%$ & $12.1 \%$ \\
\hline & & & & & & $\begin{array}{l}\text { Yorkshire and } \\
\text { the Humber }\end{array}$ & $7.1 \%$ & $8.7 \%$ \\
\hline Chi-square & 0.130 & & Chi-square & 236.825 & & Chi-square & 2.186 & \\
\hline $\begin{array}{l}\text { d.f } \\
\text { p-value }\end{array}$ & $\begin{array}{c}{[2]} \\
(0.937)\end{array}$ & & $\begin{array}{l}\text { d.f } \\
\text { p-value }\end{array}$ & $\begin{array}{c}{[6]} \\
(0,000)\end{array}$ & & $\begin{array}{l}\text { d.f } \\
\text { D-value }\end{array}$ & [11] & \\
\hline
\end{tabular}


Table 2 - Variable Description

\begin{tabular}{|c|c|c|c|c|c|c|c|}
\hline Variable & Description & Mean & $\begin{array}{l}\text { Std. } \\
\text { Deviation }\end{array}$ & Minimum & Maximum & \multicolumn{2}{|c|}{ Skewness } \\
\hline $\begin{array}{l}\text { Product } \\
\text { Innovation }\end{array}$ & $\begin{array}{l}\text { Count of number of new or significantly improved goods or services (e.g. in quality, user } \\
\text { friendliness, timelines) the company introduced in the last } 3 \text { years. }\end{array}$ & 8.685 & 19.824 & 0 & 200 & 5.610 & $(0.000)$ \\
\hline $\begin{array}{l}\text { Process } \\
\text { Innovation }\end{array}$ & $\begin{array}{l}\text { Count of number of new or significantly improved methods for production or supply of } \\
\text { goods and/or services introduced by the company in the last } 3 \text { years. }\end{array}$ & 3.819 & 8.980 & 0 & 100 & 8.572 & $(0.000)$ \\
\hline $\begin{array}{l}\text { Organisational } \\
\text { Innovation }\end{array}$ & $\begin{array}{l}\text { Count of number of times new or significantly improved forms of organisation, business } \\
\text { structures or practices (e.g. Investors in People, Just in Time, } 6 \text { Sigma) aimed at } \\
\text { improving competitiveness have been introduced in the last } 3 \text { years. }\end{array}$ & 2.458 & 10.501 & 0 & 150 & 12.127 & $(0.000)$ \\
\hline All Innovations & Sum of product, process and organisational innovations introduced in the last 3 years. & 14.961 & 29.343 & 0 & 250 & 5.133 & $(0.000)$ \\
\hline $\begin{array}{l}\text { Strategic Network } \\
\text { Ties }\end{array}$ & $\begin{array}{l}\text { Frequency ( } 0 \text { never - } 10 \text { very often) that the company uses relationships with knowledge } \\
\text { sources, which the company strategically seek to maintain and develop. }\end{array}$ & 6.121 & 3.025 & 0 & 10 & -0.538 & $(0.000)$ \\
\hline $\begin{array}{l}\text { Embedded } \\
\text { Network Ties }\end{array}$ & $\begin{array}{l}\text { Frequency ( } 0 \text { never - } 10 \text { very often) that the company uses relationships with knowledge } \\
\text { sources, which the company does not strategically seeks to maintain and develop. }\end{array}$ & 4.886 & 2.582 & 0 & 10 & -0.158 & $(0.264)$ \\
\hline All Network Ties & Sum of frequency of use of strategic and embedded network ties. & 11.007 & 4.527 & 0 & 20 & -0.388 & $(0.006)$ \\
\hline $\begin{array}{l}\text { Firm Age } 5 \text { to } 9 \\
\text { Years }\end{array}$ & Dummy representing firms aged 5 to 9 years. & 0.342 & 0.475 & 0 & 1 & $\mathrm{n} / \mathrm{a}$ & \\
\hline $\begin{array}{l}\text { Firm Age } 10 \text { or } \\
\text { more Years }\end{array}$ & Dummy representing firms aged 10 or more years. & 0.564 & 0.497 & 0 & 1 & $\mathrm{n} / \mathrm{a}$ & \\
\hline Employment & Number of employees at the time of survey. & 142.520 & 1243.081 & 0 & 21000 & 16.125 & $(0.000)$ \\
\hline $\begin{array}{l}\text { Fast growing } \\
\text { business }\end{array}$ & $\begin{array}{c}\text { Dummy representing those firms indicating that their turnover/sales have increased by } 50 \\
\text { percent or more in the last } 3 \text { years. }\end{array}$ & 0.255 & 0.437 & 0 & 1 & $\mathrm{n} / \mathrm{a}$ & \\
\hline $\begin{array}{l}\text { Significantly } \\
\text { Sufficient } \\
\text { Absorptive } \\
\text { Capacity }\end{array}$ & $\begin{array}{l}\text { Dummy representing those firms where the extent of the internal resource base (skills, } \\
\text { R\&D/innovation, IT and physical infrastructure) of the company is regarded as } \\
\text { significantly sufficient to effectively utilise and implement the knowledge sourced } \\
\text { externally. }\end{array}$ & 0.500 & 0.501 & 0 & 1 & $\mathrm{n} / \mathrm{a}$ & \\
\hline $\begin{array}{l}\text { Extremely } \\
\text { Sufficient } \\
\text { Absorptive } \\
\text { Capacity }\end{array}$ & $\begin{array}{l}\text { Dummy representing those firms where the extent of the internal resource base (skills, } \\
\text { R\&D/innovation, IT and physical infrastructure) of the company is regarded as } \\
\text { extremely sufficient to effectively utilise and implement the knowledge sourced } \\
\text { externally. }\end{array}$ & 0.138 & 0.345 & 0 & 1 & $\mathrm{n} / \mathrm{a}$ & \\
\hline Knowledge & Firms classed as High Technology Manufacturers (NACE 21, 26, 30.3) or Knowledge & & & & & & \\
\hline Intensive & $\begin{array}{c}\text { Intensive Service firms (NACE 50,51, 58, 59, 60, 61, 62, 63, 64, 65, 66, 69, 70, 71, 72, } \\
\text { 73, 74, 75, 78, 80, 84, 85, 86, 87, 88, 89, 90, 91, 92, 93) }\end{array}$ & 0.695 & 0.461 & 0 & 1 & $\mathrm{n} / \mathrm{a}$ & \\
\hline $\begin{array}{l}\text { Manufacturing } \\
\text { Firm }\end{array}$ & $\begin{array}{l}\text { Firms classed as Manufacturers (NACE 15, 16, 17, 18, 19, 20, 21, 22, 23, 24, 25, 26, 27, } \\
\qquad 28,29,30,31,32,33,34,35,36)\end{array}$ & 0.362 & 0.482 & 0 & 1 & $\mathrm{n} / \mathrm{a}$ & \\
\hline
\end{tabular}

Notes: $\mathrm{p}$-values in parentheses 
Table 3 - Comparisons of innovative outputs given frequency of use of knowledge sourcing ties

\begin{tabular}{|c|c|c|c|c|c|c|c|}
\hline & & $\begin{array}{c}\text { Frequency of } \\
\text { use }\end{array}$ & Mean & $N$ & $\begin{array}{l}\text { Standard } \\
\text { deviation }\end{array}$ & $\begin{array}{c}\text { Mann- } \\
\text { Whitney U }\end{array}$ & $\begin{array}{c}\mathrm{p}- \\
\text { value }\end{array}$ \\
\hline \multirow{7}{*}{$\begin{array}{l}\text { All } \\
\text { innovations }\end{array}$} & \multirow{2}{*}{$\begin{array}{l}\text { Strategic } \\
\text { network ties }\end{array}$} & Less frequent & 10.1 & 123 & 13.5 & \multirow[t]{2}{*}{-2.241} & \multirow[t]{2}{*}{$(0.025)$} \\
\hline & & More frequent & 18.4 & 175 & 36.2 & & \\
\hline & \multirow{2}{*}{$\begin{array}{l}\text { Embedded } \\
\text { network ties }\end{array}$} & Less frequent & 10.5 & 186 & 17.1 & \multirow[t]{2}{*}{-3.475} & \multirow[t]{2}{*}{$(0.001)$} \\
\hline & & More frequent & 22.4 & 112 & 41.5 & & \\
\hline & \multirow{4}{*}{ All ties } & Less frequent & 9.3 & 142 & 13.8 & \multirow[t]{3}{*}{-4.153} & \multirow[t]{3}{*}{$(0.000)$} \\
\hline & & More frequent & 20.2 & 156 & 37.7 & & \\
\hline & & firms & 15.0 & 298 & 29.3 & & \\
\hline & & $\begin{array}{c}\text { Frequency of } \\
\text { use }\end{array}$ & Mean & $N$ & $\begin{array}{l}\text { Standard } \\
\text { deviation }\end{array}$ & $\begin{array}{c}\text { Mann- } \\
\text { Whitney U }\end{array}$ & $\begin{array}{c}\mathrm{p}- \\
\text { value }\end{array}$ \\
\hline \multirow{7}{*}{$\begin{array}{l}\text { Product } \\
\text { innovations }\end{array}$} & \multirow{2}{*}{$\begin{array}{l}\text { Strategic } \\
\text { network ties }\end{array}$} & Less frequent & 6.0 & 123 & 10.7 & \multirow[t]{2}{*}{-2.001} & \multirow[t]{2}{*}{$(0.045)$} \\
\hline & & More frequent & 10.6 & 175 & 24.1 & & \\
\hline & \multirow{2}{*}{$\begin{array}{l}\text { Embedded } \\
\text { network ties }\end{array}$} & Less frequent & 5.6 & 186 & 10.9 & \multirow[t]{2}{*}{-3.136} & \multirow[t]{2}{*}{$(0.002)$} \\
\hline & & More frequent & 13.8 & 112 & 28.5 & & \\
\hline & \multirow{3}{*}{ All ties } & Less frequent & 5.7 & 142 & 12.1 & \multirow[t]{3}{*}{-3.268} & \multirow[t]{3}{*}{$(0.001)$} \\
\hline & & More frequent & 11.4 & 156 & 24.6 & & \\
\hline & & firms & 8.7 & 298 & 19.8 & & \\
\hline \multirow{9}{*}{$\begin{array}{l}\text { Process } \\
\text { innovations }\end{array}$} & & $\begin{array}{c}\text { Frequency of } \\
\text { use }\end{array}$ & Mean & $N$ & $\begin{array}{l}\text { Standard } \\
\text { deviation }\end{array}$ & $\begin{array}{c}\text { Mann- } \\
\text { Whitney U }\end{array}$ & $\begin{array}{c}\mathrm{p}- \\
\text { value }\end{array}$ \\
\hline & \multirow{2}{*}{$\begin{array}{l}\text { Strategic } \\
\text { network ties }\end{array}$} & Less frequent & 2.6 & 123 & 3.5 & \multirow[t]{2}{*}{-2.016} & \multirow[t]{2}{*}{$(0.044)$} \\
\hline & & More frequent & 4.6 & 175 & 11.3 & & \\
\hline & \multirow{2}{*}{$\begin{array}{l}\text { Embedded } \\
\text { network ties }\end{array}$} & Less frequent & 2.7 & 186 & 3.5 & \multirow[t]{2}{*}{-2.713} & \multirow[t]{2}{*}{$(0.007)$} \\
\hline & & More frequent & 5.7 & 112 & 13.8 & & \\
\hline & \multirow{4}{*}{ All ties } & Less frequent & 2.4 & 142 & 3.5 & \multirow[t]{3}{*}{-3.903} & $(0.000)$ \\
\hline & & More frequent & 5.1 & 156 & 11.8 & & \\
\hline & & firms & 3.8 & 298 & 9.0 & & \\
\hline & & $\begin{array}{c}\text { Frequency of } \\
\text { use }\end{array}$ & Mean & $N$ & $\begin{array}{l}\text { Standard } \\
\text { deviation }\end{array}$ & $\begin{array}{c}\text { Mann- } \\
\text { Whitney U }\end{array}$ & $\begin{array}{c}\mathrm{p}- \\
\text { value }\end{array}$ \\
\hline & Strategic & Less frequent & 1.5 & 123 & 1.9 & -1.044 & $(0.296)$ \\
\hline & network ties & More frequent & 3.2 & 175 & 13.6 & & \\
\hline & Embedded & Less frequent & 2.2 & 186 & 11.0 & -1.948 & $(0.051)$ \\
\hline innovations & network ties & More frequent & 3.0 & 112 & 9.6 & & \\
\hline & All ties & Less frequent & 1.2 & 142 & 1.6 & -3.164 & $(0.002)$ \\
\hline & All nes & More frequent & 3.6 & 156 & 14.4 & & \\
\hline & & firms & 2.5 & 298 & 10.5 & & \\
\hline
\end{tabular}

Notes: p-values in parentheses 
Table 4 - Correlation matrix for firm innovations

\begin{tabular}{|c|c|c|c|c|c|c|c|c|c|c|c|c|c|c|}
\hline & $\begin{array}{l}\text { 1. Product } \\
\text { Innovations }\end{array}$ & 2 & 3 & 4 & 5 & 6 & 7 & 8 & 9 & 10 & 11 & 12 & 13 & 14 \\
\hline 2. Process Innovations & $\begin{array}{l}0.416 \\
(0.000)\end{array}$ & & & & & & & & & & & & & \\
\hline $\begin{array}{l}\text { 3. Organisational } \\
\text { Innovations }\end{array}$ & $\begin{array}{c}0.112 \\
(0.053)\end{array}$ & $\begin{array}{l}0.437 \\
(0.000)\end{array}$ & & & & & & & & & & & & \\
\hline 4. All Innovations & $\begin{array}{c}0.843 \\
(0.000)\end{array}$ & $\begin{array}{l}0.743 \\
(0.000)\end{array}$ & $\begin{array}{c}0.567 \\
(0.000)\end{array}$ & & & & & & & & & & & \\
\hline 5. Strategic network ties & $\begin{array}{c}0.126 \\
(0.030)\end{array}$ & $\begin{array}{l}0.128 \\
(0.027)\end{array}$ & $\begin{array}{c}0.120 \\
(0.039)\end{array}$ & $\begin{array}{l}0.167 \\
(0.004)\end{array}$ & & & & & & & & & & \\
\hline $\begin{array}{l}\text { 6. Embedded network } \\
\text { ties }\end{array}$ & $\begin{array}{c}0.148 \\
(0.011)\end{array}$ & $\begin{array}{c}0.151 \\
(0.009)\end{array}$ & $\begin{array}{l}0.087 \\
(0.136)\end{array}$ & $\begin{array}{l}0.177 \\
(0.002)\end{array}$ & $\begin{array}{c}0.299 \\
(0.000)\end{array}$ & & & & & & & & & \\
\hline 7. All Partnerships & $\begin{array}{l}0.168 \\
(0.004)\end{array}$ & $\begin{array}{c}0.171 \\
(0.003)\end{array}$ & $\begin{array}{c}0.129 \\
(0.026)\end{array}$ & $\begin{array}{c}0.212 \\
(0.000)\end{array}$ & $\begin{array}{c}0.839 \\
(0.000)\end{array}$ & $\begin{array}{c}0.770 \\
(0.000)\end{array}$ & & & & & & & & \\
\hline $\begin{array}{l}\text { 8. Firms Aged } 4 \text { to } 9 \\
\text { Years }\end{array}$ & $\begin{array}{l}-0.051 \\
(0.383)\end{array}$ & $\begin{array}{l}-0.036 \\
(0.537)\end{array}$ & $\begin{array}{l}-0.087 \\
(0.133)\end{array}$ & $\begin{array}{l}-0.076 \\
(0.188)\end{array}$ & $\begin{array}{l}0.130 \\
(0.024)\end{array}$ & $\begin{array}{c}0.062 \\
(0.285)\end{array}$ & $\begin{array}{l}0.123 \\
(0.034)\end{array}$ & & & & & & & \\
\hline $\begin{array}{l}\text { 9. Firms Aged } 10 \text { or more } \\
\text { years }\end{array}$ & $\begin{array}{c}0.090 \\
(0.120)\end{array}$ & $\begin{array}{l}0.053 \\
(0.360)\end{array}$ & $\begin{array}{c}0.102 \\
(0.079)\end{array}$ & $\begin{array}{c}0.114 \\
(0.050)\end{array}$ & $\begin{array}{l}-0.113 \\
(0.052)\end{array}$ & $\begin{array}{l}-0.099 \\
(0.087)\end{array}$ & $\begin{array}{l}-0.132 \\
(0.023)\end{array}$ & $\begin{array}{l}-0.820 \\
(0.000)\end{array}$ & & & & & & \\
\hline 10. Firm Employment & $\begin{array}{c}0.171 \\
(0.003)\end{array}$ & $\begin{array}{c}0.310 \\
(0.000)\end{array}$ & $\begin{array}{l}0.227 \\
(0.000)\end{array}$ & $\begin{array}{c}0.291 \\
(0.000)\end{array}$ & $\begin{array}{c}0.050 \\
(0.390)\end{array}$ & $\begin{array}{c}0.085 \\
(0.142)\end{array}$ & $\begin{array}{c}0.082 \\
(0.158)\end{array}$ & $\begin{array}{l}-0.269 \\
(0.000)\end{array}$ & $\begin{array}{l}0.368 \\
(0.000)\end{array}$ & & & & & \\
\hline 11. Fast Growing Firm & $\begin{array}{l}-0.032 \\
(0.588)\end{array}$ & $\begin{array}{l}-0.046 \\
(0.432)\end{array}$ & $\begin{array}{l}-0.053 \\
(0.358)\end{array}$ & $\begin{array}{l}-0.054 \\
(0.349)\end{array}$ & $\begin{array}{c}0.109 \\
(0.060)\end{array}$ & $\begin{array}{c}0.029 \\
(0.619)\end{array}$ & $\begin{array}{l}0.089 \\
(0.124)\end{array}$ & $\begin{array}{c}0.194 \\
(0.001)\end{array}$ & $\begin{array}{l}-0.199 \\
(0.001)\end{array}$ & $\begin{array}{l}-0.105 \\
(0.070)\end{array}$ & & & & \\
\hline $\begin{array}{l}\text { 12. Significantly Sufficient } \\
\text { Absorptive Capacity }\end{array}$ & $\begin{array}{l}-0.137 \\
(0.018)\end{array}$ & $\begin{array}{l}-0.029 \\
(0.616)\end{array}$ & $\begin{array}{c}0.072 \\
(0.218)\end{array}$ & $\begin{array}{l}-0.076 \\
(0.190)\end{array}$ & $\begin{array}{c}0.002 \\
(0.970)\end{array}$ & $\begin{array}{c}0.039 \\
(0.502)\end{array}$ & $\begin{array}{c}0.024 \\
(0.683)\end{array}$ & $\begin{array}{l}-0.085 \\
(0.144)\end{array}$ & $\begin{array}{c}0.068 \\
(0.244)\end{array}$ & $\begin{array}{c}0.018 \\
(0.756)\end{array}$ & $\begin{array}{l}-0.031 \\
(0.596)\end{array}$ & & & \\
\hline $\begin{array}{l}\text { 13. Extremely Sufficient } \\
\text { Absorptive Capacity }\end{array}$ & $\begin{array}{c}0.014 \\
(0.810)\end{array}$ & $\begin{array}{l}0.028 \\
(0.628)\end{array}$ & $\begin{array}{l}-0.041 \\
(0.484)\end{array}$ & $\begin{array}{c}0.004 \\
(0.952)\end{array}$ & $\begin{array}{c}0.074 \\
(0.201)\end{array}$ & $\begin{array}{l}-0.099 \\
(0.086)\end{array}$ & $\begin{array}{l}-0.007 \\
(0.903)\end{array}$ & $\begin{array}{c}0.061 \\
(0.295)\end{array}$ & $\begin{array}{l}-0.061 \\
(0.293)\end{array}$ & $\begin{array}{l}-0.075 \\
(0.194)\end{array}$ & $\begin{array}{l}-0.010 \\
(0.861)\end{array}$ & $\begin{array}{l}-0.399 \\
(0.000)\end{array}$ & & \\
\hline $\begin{array}{l}\text { 14. Knowledge Intensive } \\
\text { Firm }\end{array}$ & $\begin{array}{l}-0.134 \\
(0.021)\end{array}$ & $\begin{array}{l}-0.070 \\
(0.229)\end{array}$ & $\begin{array}{l}-0.054 \\
(0.349)\end{array}$ & $\begin{array}{l}-0.131 \\
(0.023)\end{array}$ & $\begin{array}{l}-0.007 \\
(0.901)\end{array}$ & $\begin{array}{c}0.002 \\
(0.976)\end{array}$ & $\begin{array}{c}-0.004 \\
(0.947)\end{array}$ & $\begin{array}{c}0.187 \\
(0.001)\end{array}$ & $\begin{array}{c}-0.231 \\
(0.000)\end{array}$ & $\begin{array}{l}-0.286 \\
(0.000)\end{array}$ & $\begin{array}{c}0.037 \\
(0.526)\end{array}$ & $\begin{array}{c}0.080 \\
(0.168)\end{array}$ & $\begin{array}{c}0.074 \\
(0.200)\end{array}$ & \\
\hline 15. Manufacturing Firm & $\begin{array}{c}0.089 \\
(0.125)\end{array}$ & $\begin{array}{c}0.083 \\
(0.155)\end{array}$ & $\begin{array}{c}0.051 \\
(0.381)\end{array}$ & $\begin{array}{c}0.104 \\
(0.074)\end{array}$ & $\begin{array}{c}0.000 \\
(0.999)\end{array}$ & $\begin{array}{c}-0.118 \\
(0.041)\end{array}$ & $\begin{array}{c}-0.068 \\
(0.245)\end{array}$ & $\begin{array}{l}-0.235 \\
(0.000)\end{array}$ & $\begin{array}{c}0.297 \\
(0.000)\end{array}$ & $\begin{array}{c}0.289 \\
(0.000)\end{array}$ & $\begin{array}{c}0.023 \\
(0.688)\end{array}$ & $\begin{array}{c}-0.014 \\
(0.810)\end{array}$ & $\begin{array}{c}0.003 \\
(0.961)\end{array}$ & $\begin{array}{l}-0.500 \\
(0.000)\end{array}$ \\
\hline
\end{tabular}

Notes: p-values in parentheses 
Table 5 Regressions of all innovations on knowledge sourcing ties

\begin{tabular}{|c|c|c|c|c|c|c|c|c|}
\hline & \multicolumn{2}{|c|}{ Poisson Model } & \multicolumn{2}{|c|}{$\begin{array}{l}\text { Negative-Binominal } \\
\text { Model }\end{array}$} & \multicolumn{2}{|c|}{ Zero-inflated Poisson Model } & \multicolumn{2}{|c|}{$\begin{array}{l}\text { Zero-inflated Negative } \\
\text { Binominal Model }\end{array}$} \\
\hline & Full Sample & $\begin{array}{l}\text { Restricted } \\
\text { Sample }\end{array}$ & $\begin{array}{c}\text { Full } \\
\text { Sample }\end{array}$ & $\begin{array}{l}\text { Restricted } \\
\text { Sample }\end{array}$ & Full Sample & $\begin{array}{l}\text { Restricted } \\
\text { Sample }\end{array}$ & Full Sample & $\begin{array}{l}\text { Restricted } \\
\text { Sample }\end{array}$ \\
\hline Strategic network ties & $\begin{array}{c}0.1051^{* * *} \\
(17.020)\end{array}$ & $\begin{array}{l}0.0065 \\
(0.900)\end{array}$ & $\begin{array}{l}0.0894 * * * \\
(4.520)\end{array}$ & $\begin{array}{l}0.0073 \\
(0.450)\end{array}$ & $\begin{array}{c}0.1034^{* * *} \\
(16.880)\end{array}$ & $\begin{array}{l}0.0039 \\
(0.530)\end{array}$ & $\begin{array}{l}0.0816^{* * *} \\
(4.180)\end{array}$ & $\begin{array}{l}0.0062 \\
(0.390)\end{array}$ \\
\hline Embedded network ties & $\begin{array}{c}0.1093^{* * *} \\
(16.740)\end{array}$ & $\begin{array}{l}0.0519 * * * \\
(6.160)\end{array}$ & $\begin{array}{l}0.0535^{*} \\
(2.290)\end{array}$ & $\begin{array}{c}0.0527^{* *} \\
(2.630)\end{array}$ & $\begin{array}{c}0.1053^{* * *} \\
(16.220)\end{array}$ & $\begin{array}{l}0.0552^{* * *} \\
(6.590)\end{array}$ & $\begin{array}{l}0.0511^{*} \\
(2.230)\end{array}$ & $\begin{array}{c}0.0559 * * \\
(2.910)\end{array}$ \\
\hline $\begin{array}{l}\text { Small firm (10 to } 49 \\
\text { employees) }\end{array}$ & $\begin{array}{l}0.0903^{*} \\
(2.110)\end{array}$ & $\begin{array}{c}0.3844 * * * \\
(7.440)\end{array}$ & $\begin{array}{l}0.0883 \\
(0.600)\end{array}$ & $\begin{array}{c}0.3687^{* *} \\
(3.320)\end{array}$ & $\begin{array}{c}0.2317^{* * *} \\
(5.650)\end{array}$ & $\begin{array}{c}0.4094^{* * *} \\
(8.330)\end{array}$ & $\begin{array}{l}0.2102 \\
(1.540)\end{array}$ & $\begin{array}{l}0.4005^{* * *} \\
(3.970)\end{array}$ \\
\hline $\begin{array}{l}\text { Medium-sized firm (50 to } 249 \\
\text { employees) }\end{array}$ & $\begin{array}{c}0.5242^{* * *} \\
(12.000)\end{array}$ & $\begin{array}{l}0.5520^{* * *} \\
(9.510)\end{array}$ & $\begin{array}{c}0.4945^{* *} \\
(2.950)\end{array}$ & $\begin{array}{l}0.5728^{* * *} \\
(4.250)\end{array}$ & $\begin{array}{c}0.7721 * * * \\
(19.170)\end{array}$ & $\begin{array}{c}0.6273 * * * \\
(11.850)\end{array}$ & $\begin{array}{l}0.6501 * * * \\
(4.090)\end{array}$ & $\begin{array}{c}0.6666^{* * *} \\
(5.640)\end{array}$ \\
\hline $\begin{array}{l}\text { Large firm ( } 250 \text { or more } \\
\text { employees) }\end{array}$ & $\begin{array}{c}0.8676^{* * *} \\
(16.650)\end{array}$ & & $\begin{array}{l}0.8018^{* *} \\
(3.110)\end{array}$ & & $\begin{array}{c}1.0978^{* * *} \\
(22.870)\end{array}$ & & $\begin{array}{c}1.0554^{* * *} \\
(4.260)\end{array}$ & \\
\hline Fast growing business & $\begin{array}{l}-0.1733^{* * *} \\
(4.470)\end{array}$ & $\begin{array}{c}0.1153^{* *} \\
(2.400)\end{array}$ & $\begin{array}{l}-0.1437 \\
(1.050)\end{array}$ & $\begin{array}{l}0.1456 \\
(1.370)\end{array}$ & $\begin{array}{l}-0.2460 * * * \\
(6.520)\end{array}$ & $\begin{array}{l}0.0811 \dagger \\
(1.750)\end{array}$ & $\begin{array}{l}-0.1712 \\
(1.280)\end{array}$ & $\begin{array}{l}0.1264 \\
(1.240)\end{array}$ \\
\hline $\begin{array}{l}\text { Significant sufficient } \\
\text { absorptive capacity }\end{array}$ & $\begin{array}{c}-0.3797 * * * \\
(11.460)\end{array}$ & $\begin{array}{l}0.0291 \\
(0.620)\end{array}$ & $\begin{array}{c}-0.2645^{*} \\
(2.060)\end{array}$ & $\begin{array}{l}0.0355 \\
(0.350)\end{array}$ & $\begin{array}{c}-0.4239 * * * \\
(12.970)\end{array}$ & $\begin{array}{l}-0.0015 \\
(0.030)\end{array}$ & $\begin{array}{c}-0.3340 * * \\
(2.630)\end{array}$ & $\begin{array}{l}0.0115 \\
(0.120)\end{array}$ \\
\hline $\begin{array}{l}\text { Extremely sufficient } \\
\text { absorptive capacity }\end{array}$ & $\begin{array}{c}-0.1030 * \\
(2.160)\end{array}$ & $\begin{array}{l}0.5065^{* * *} \\
(8.330)\end{array}$ & $\begin{array}{l}0.1117 \\
(0.590)\end{array}$ & $\begin{array}{l}0.5213^{* * *} \\
(3.600)\end{array}$ & $\begin{array}{c}-0.1362^{* *} \\
(2.900)\end{array}$ & $\begin{array}{l}0.4978^{* * *} \\
(8.300)\end{array}$ & $\begin{array}{l}0.0212 \\
(0.120)\end{array}$ & $\begin{array}{c}0.5201 * * * \\
(3.680)\end{array}$ \\
\hline 4 to 9 years old & $\begin{array}{c}0.1900 * * \\
(2.670)\end{array}$ & $\begin{array}{l}-0.0975 \\
(1.290)\end{array}$ & $\begin{array}{l}0.0943 \\
(0.420)\end{array}$ & $\begin{array}{l}-0.0979 \\
(0.590)\end{array}$ & $\begin{array}{l}-2.1178 \\
(1.490)\end{array}$ & $\begin{array}{l}-2.1263 \\
(1.380)\end{array}$ & $\begin{array}{c}-19.5131 \\
(0.000)\end{array}$ & $\begin{array}{c}-19.2644 \\
(0.000)\end{array}$ \\
\hline 10 years old or more & $\begin{array}{c}0.4402^{* * *} \\
(6.380)\end{array}$ & $\begin{array}{l}-0.0733 \\
(0.980)\end{array}$ & $\begin{array}{l}0.3087 \\
(1.360)\end{array}$ & $\begin{array}{l}-0.0918 \\
(0.540)\end{array}$ & $\begin{array}{l}-20.7410 \\
(0.000)\end{array}$ & $\begin{array}{c}-19.0781 \\
(0.010)\end{array}$ & $\begin{array}{c}-20.3704 \\
(0.000)\end{array}$ & $\begin{array}{c}-38.0578 \\
(0.000)\end{array}$ \\
\hline Knowledge intensive & $\begin{array}{c}-0.1801^{* * *} \\
(4.930)\end{array}$ & $\begin{array}{l}-0.0671 \\
(1.310)\end{array}$ & $\begin{array}{l}-0.1797 \\
(1.180)\end{array}$ & $\begin{array}{l}-0.0866 \\
(0.750)\end{array}$ & $\begin{array}{l}-2.5829 \\
(1.630)\end{array}$ & $\begin{array}{c}-2.6867 \dagger \\
(1.560)\end{array}$ & $\begin{array}{c}-17.1912 \\
(0.000)\end{array}$ & $\begin{array}{c}-20.1581 \\
(0.000)\end{array}$ \\
\hline
\end{tabular}

Notes: t-statistics in parentheses; coefficients significant at *** 0.1 percent level, ${ }^{* *} 1$ percent level, * 5 percent level, $† 10$ percent level.

Table 5 continued 


\begin{tabular}{|c|c|c|c|c|c|c|c|c|}
\hline & \multicolumn{2}{|c|}{ Poisson Model } & \multicolumn{2}{|c|}{$\begin{array}{l}\text { Negative-Binominal } \\
\text { Model }\end{array}$} & \multicolumn{2}{|c|}{ Zero-inflated Poisson Model } & \multicolumn{2}{|c|}{$\begin{array}{l}\text { Zero-inflated Negative } \\
\text { Binominal Model }\end{array}$} \\
\hline & $\begin{array}{c}\text { Full } \\
\text { Sample }\end{array}$ & $\begin{array}{l}\text { Restricted } \\
\text { Sample }\end{array}$ & $\begin{array}{c}\text { Full } \\
\text { Sample }\end{array}$ & $\begin{array}{l}\text { Restricted } \\
\text { Sample }\end{array}$ & $\begin{array}{c}\text { Full } \\
\text { Sample }\end{array}$ & $\begin{array}{l}\text { Restricted } \\
\text { Sample }\end{array}$ & Full Sample & $\begin{array}{l}\text { Restricted } \\
\text { Sample }\end{array}$ \\
\hline Manufacturing & $\begin{array}{c}0.1692 * * * \\
(4.590)\end{array}$ & $\begin{array}{c}0.1515 * * \\
(2.970)\end{array}$ & $\begin{array}{l}0.1144 \\
(0.760)\end{array}$ & $\begin{array}{l}0.1377 \\
(1.190)\end{array}$ & $\begin{array}{l}-0.8879 \\
(0.560)\end{array}$ & $\begin{array}{r}-1.3381 \\
(0.760)\end{array}$ & $\begin{array}{l}18.1479 \\
(0.000)\end{array}$ & $\begin{array}{c}-18.0497 \\
(0.000)\end{array}$ \\
\hline Constant & $\begin{array}{c}1.1208 * * * \\
(12.610)\end{array}$ & $\begin{array}{c}1.5592 * * * \\
(14.730)\end{array}$ & $\begin{array}{c}1.5838 * * * \\
(5.520)\end{array}$ & $\begin{array}{c}1.5668 * * * \\
(6.800)\end{array}$ & $\begin{array}{c}1.3654^{* * *} \\
(22.950)\end{array}$ & $\begin{array}{c}1.5123 * * * \\
(21.250)\end{array}$ & $\begin{array}{c}1.7531 * * * \\
(10.170)\end{array}$ & $\begin{array}{c}1.4621 * * * * \\
(10.140)\end{array}$ \\
\hline $\begin{array}{l}\text { Constant (Logit of zero-inflated } \\
\text { binominal regressions) }\end{array}$ & & & & & $\begin{array}{l}-0.5906 \\
(0.410)\end{array}$ & $\begin{array}{l}-0.1335 \\
(0.070)\end{array}$ & $\begin{array}{c}-19.4497 \\
(0.000)\end{array}$ & $\begin{array}{c}16.8591 \\
(0.000)\end{array}$ \\
\hline$N$ & 298 & 267 & 298 & 267 & 298 & 267 & 298 & 267 \\
\hline Chi squared test & 1940.4 & 266.0 & 91.5 & 51.1 & 1784.5 & 255.5 & 82.4 & 51.2 \\
\hline [d.f $]$ & {$[12]$} & [11] & [12] & [11] & {$[8]$} & [7] & {$[8]$} & [7] \\
\hline p-value & $(0.000)$ & $(0.000)$ & $(0.000)$ & $(0.000)$ & $(0.000)$ & $(0.000)$ & $(0.000)$ & $(0.000)$ \\
\hline$R^{2}$ & 0.229 & 0.105 & 0.041 & 0.030 & $\mathrm{n} / \mathrm{a}$ & $\mathrm{n} / \mathrm{a}$ & $\mathrm{n} / \mathrm{a}$ & $\mathrm{n} / \mathrm{a}$ \\
\hline Dispersion variable $(\theta)$ & $\mathrm{n} / \mathrm{a}$ & $\mathrm{n} / \mathrm{a}$ & 0.873 & 0.415 & $\mathrm{n} / \mathrm{a}$ & $\mathrm{n} / \mathrm{a}$ & 0.890 & 0.395 \\
\hline $\begin{array}{l}\text { LR-test of } \theta \\
\text { p-value }\end{array}$ & $\mathrm{n} / \mathrm{a}$ & $\mathrm{n} / \mathrm{a}$ & $\begin{array}{l}4400.1 \\
(0.000)\end{array}$ & $\begin{array}{c}629.2 \\
(0.000)\end{array}$ & $\mathrm{n} / \mathrm{a}$ & $\mathrm{n} / \mathrm{a}$ & $\mathrm{n} / \mathrm{a}$ & $\mathrm{n} / \mathrm{a}$ \\
\hline $\begin{array}{l}\text { Vuong test } \\
\text { p-value }\end{array}$ & $\mathrm{n} / \mathrm{a}$ & $\mathrm{n} / \mathrm{a}$ & $\mathrm{n} / \mathrm{a}$ & $\mathrm{n} / \mathrm{a}$ & $\begin{array}{c}1.12 \\
(0.132) \\
\end{array}$ & $\begin{array}{c}1.58 \\
(0.057) \\
\end{array}$ & $\begin{array}{c}0.570 \\
(0.284) \\
\end{array}$ & $\begin{array}{c}1.030 \\
(0.152) \\
\end{array}$ \\
\hline
\end{tabular}

Notes: t-statistics in parentheses; coefficients significant at ${ }^{* * *} 0.1$ percent level, ${ }^{* *} 1$ percent level, $* 5$ percent level, $† 10$ percent level. 
Table 6 Negative binominal regressions of product, process and organisational innovations on knowledge sourcing ties

\begin{tabular}{|c|c|c|c|c|c|c|}
\hline & \multicolumn{2}{|c|}{ Product Innovations } & \multicolumn{2}{|c|}{ Process Innovations } & \multicolumn{2}{|c|}{ Organisational Innovations } \\
\hline & Full Sample & $\begin{array}{c}\text { Restricted } \\
\text { Sample }\end{array}$ & Full Sample & $\begin{array}{c}\text { Restricted } \\
\text { Sample }\end{array}$ & Full Sample & $\begin{array}{c}\text { Restricted } \\
\text { Sample }\end{array}$ \\
\hline Strategic network ties & $\begin{array}{c}0.0780^{* * *} \\
(3.560)\end{array}$ & $\begin{array}{l}-0.0072 \\
(0.410)\end{array}$ & $\begin{array}{c}0.0510 \dagger \\
(1.950)\end{array}$ & $\begin{array}{l}0.0246 \\
(1.000)\end{array}$ & $\begin{array}{c}0.1237^{* * *} \\
(4.250)\end{array}$ & $\begin{array}{l}0.0317 \\
(1.250)\end{array}$ \\
\hline Embedded network ties & $\begin{array}{c}0.0554^{*} \\
(2.200)\end{array}$ & $\begin{array}{c}0.0475^{*} \\
(2.210)\end{array}$ & $\begin{array}{c}0.0821^{* *} \\
(2.670)\end{array}$ & $\begin{array}{l}0.0485 \\
(1.620)\end{array}$ & $\begin{array}{c}0.0634 \dagger \\
(1.810)\end{array}$ & $\begin{array}{c}0.0716^{*} \\
(2.400)\end{array}$ \\
\hline Small firm (10 to 49 employees) & $\begin{array}{l}-0.1907 \\
(1.180)\end{array}$ & $\begin{array}{c}0.3668^{* *} \\
(3.100)\end{array}$ & $\begin{array}{l}0.2567 \\
(1.390)\end{array}$ & $\begin{array}{l}0.2288 \\
(1.330)\end{array}$ & $\begin{array}{c}0.9736^{* * *} \\
(4.660)\end{array}$ & $\begin{array}{c}0.7118^{* * *} \\
(4.030)\end{array}$ \\
\hline Medium-sized firm (50 to 249 employees) & $\begin{array}{l}0.2842 \\
(1.530)\end{array}$ & $\begin{array}{c}0.4399 * * \\
(3.040)\end{array}$ & $\begin{array}{c}0.8271^{* * *} \\
(4.040)\end{array}$ & $\begin{array}{c}0.5176^{* *} \\
(2.510)\end{array}$ & $\begin{array}{c}1.0909 * * * \\
(4.550)\end{array}$ & $\begin{array}{c}1.1150^{* * *} \\
(5.670)\end{array}$ \\
\hline Large firm (250 or more employees) & $\begin{array}{l}0.4016 \\
(1.400)\end{array}$ & & $\begin{array}{c}1.3497^{* * *} \\
(4.480)\end{array}$ & & $\begin{array}{c}1.5140 * * * \\
(4.450)\end{array}$ & \\
\hline Fast growing business & $\begin{array}{l}-0.1001 \\
(0.660)\end{array}$ & $\begin{array}{c}0.2133 \dagger \\
(1.900)\end{array}$ & $\begin{array}{l}-0.0056 \\
(0.030)\end{array}$ & $\begin{array}{l}0.1320 \\
(0.800)\end{array}$ & $\begin{array}{l}-0.2425 \\
(1.190)\end{array}$ & $\begin{array}{l}-0.0401 \\
(0.240)\end{array}$ \\
\hline Significant sufficient absorptive capacity & $\begin{array}{c}-0.4440 * * \\
(3.090)\end{array}$ & $\begin{array}{l}0.0722 \\
(0.660)\end{array}$ & $\begin{array}{l}-0.1992 \\
(1.270)\end{array}$ & $\begin{array}{l}0.0623 \\
(0.410)\end{array}$ & $\begin{array}{l}0.0769 \\
(0.410)\end{array}$ & $\begin{array}{l}-0.1459 \\
(0.950)\end{array}$ \\
\hline Extremely sufficient absorptive capacity & $\begin{array}{l}0.0531 \\
(0.260)\end{array}$ & $\begin{array}{c}0.6065^{* * *} \\
(3.970)\end{array}$ & $\begin{array}{l}0.2977 \\
(1.330)\end{array}$ & $\begin{array}{c}0.5767^{* *} \\
(2.690)\end{array}$ & $\begin{array}{l}-0.1297 \\
(0.460)\end{array}$ & $\begin{array}{l}0.0347 \\
(0.150)\end{array}$ \\
\hline 4 to 9 years old & $\begin{array}{l}0.3189 \\
(1.280)\end{array}$ & $\begin{array}{l}0.1010 \\
(0.570)\end{array}$ & $\begin{array}{l}-0.1530 \\
(0.560)\end{array}$ & $\begin{array}{l}-0.3593 \\
(1.450)\end{array}$ & $\begin{array}{l}-0.2281 \\
(0.710)\end{array}$ & $\begin{array}{l}-0.2408 \\
(0.930)\end{array}$ \\
\hline 10 years old or more & $\begin{array}{c}0.4416 \dagger \\
(1.740)\end{array}$ & $\begin{array}{l}-0.0257 \\
(0.140)\end{array}$ & $\begin{array}{l}-0.1235 \\
(0.440)\end{array}$ & $\begin{array}{l}-0.1699 \\
(0.670)\end{array}$ & $\begin{array}{l}0.3371 \\
(1.080)\end{array}$ & $\begin{array}{l}-0.0346 \\
(0.140)\end{array}$ \\
\hline Knowledge intensive & $\begin{array}{l}-0.2487 \\
(1.500)\end{array}$ & $\begin{array}{l}-0.0766 \\
(0.620)\end{array}$ & $\begin{array}{l}0.0371 \\
(0.200)\end{array}$ & $\begin{array}{l}-0.0761 \\
(0.430)\end{array}$ & $\begin{array}{l}-0.0974 \\
(0.460)\end{array}$ & $\begin{array}{l}-0.0838 \\
(0.490)\end{array}$ \\
\hline
\end{tabular}

Notes: t-statistics in parentheses; coefficients significant at *** 0.1 percent level, ** 1 percent level, * 5 percent level, $† 10$ percent level. 
Table 6 continued

\begin{tabular}{|c|c|c|c|c|c|c|}
\hline & \multicolumn{2}{|c|}{ Product Innovations } & \multicolumn{2}{|c|}{ Process Innovations } & \multicolumn{2}{|c|}{ Organisational Innovations } \\
\hline & Full Sample & $\begin{array}{l}\text { Restricted } \\
\text { Sample }\end{array}$ & Full Sample & $\begin{array}{c}\text { Restricted } \\
\text { Sample }\end{array}$ & Full Sample & $\begin{array}{c}\text { Restricted } \\
\text { Sample }\end{array}$ \\
\hline Manufacturing & $\begin{array}{l}0.1488 \\
(0.910)\end{array}$ & $\begin{array}{l}0.1149 \\
(0.930)\end{array}$ & $\begin{array}{l}0.2476 \\
(1.330)\end{array}$ & $\begin{array}{l}0.1410 \\
(0.790)\end{array}$ & $\begin{array}{l}-0.0229 \\
(0.110)\end{array}$ & $\begin{array}{l}0.2319 \\
(1.360)\end{array}$ \\
\hline Constant & $\begin{array}{c}1.2242^{* * *} \\
(3.740)\end{array}$ & $\begin{array}{c}0.9512^{* * *} \\
(3.750)\end{array}$ & $\begin{array}{l}0.1761 \\
(0.500)\end{array}$ & $\begin{array}{l}0.4353 \\
(1.300)\end{array}$ & $\begin{array}{c}-1.1874^{* *} \\
(2.810)\end{array}$ & $\begin{array}{c}-0.6633 \dagger \\
(1.850)\end{array}$ \\
\hline$N$ & 298 & 267 & 298 & 267 & 298 & 267 \\
\hline $\begin{array}{l}\text { Chi squared test } \\
\text { [d.f] } \\
\text { p-value }\end{array}$ & $\begin{array}{c}78.5 \\
{[12]} \\
(0.000)\end{array}$ & $\begin{array}{c}38.9 \\
{[11]} \\
(0.000)\end{array}$ & $\begin{array}{c}69.9 \\
{[12]} \\
(0.000)\end{array}$ & $\begin{array}{c}26.2 \\
{[11]} \\
(0.006)\end{array}$ & $\begin{array}{c}103.8 \\
{[12]} \\
(0.000)\end{array}$ & $\begin{array}{c}61.5 \\
{[11]} \\
(0.000)\end{array}$ \\
\hline$R^{2}$ & 0.041 & 0.028 & 0.048 & 0.023 & 0.088 & 0.070 \\
\hline Dispersion variable $(\theta)$ & 1.024 & 0.404 & 1.096 & 0.808 & 1.245 & 0.467 \\
\hline $\begin{array}{l}\text { LR-test of } \theta \\
\text { p-value }\end{array}$ & $\begin{array}{l}3020.7 \\
(0.000) \\
\end{array}$ & $\begin{array}{c}302.1 \\
(0.000) \\
\end{array}$ & $\begin{array}{c}988.7 \\
(0.000) \\
\end{array}$ & $\begin{array}{c}275.9 \\
(0.000) \\
\end{array}$ & $\begin{array}{c}994.9 \\
(0.000) \\
\end{array}$ & $\begin{array}{c}41.3 \\
(0.000)\end{array}$ \\
\hline
\end{tabular}

Notes: t-statistics in parentheses; coefficients significant at *** 0.1 percent level, ** 1 percent level, * 5 percent level, $† 10$ percent level. 